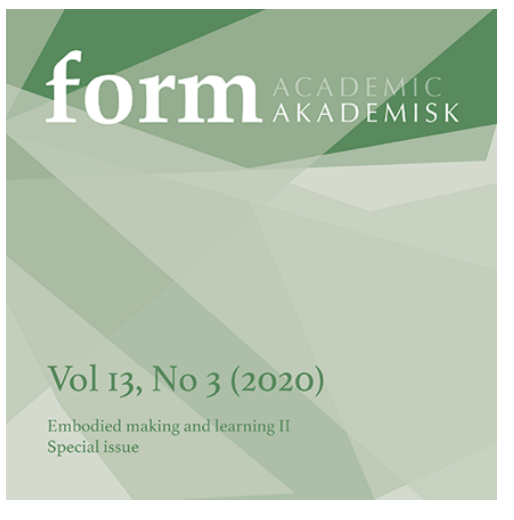

\section{Ellen Baskår}

Universitetslektor

Fakultet for humaniora, idretts- og utdanningsvitenskap Institutt for estetiske fag, Campus Notodden Universitetet i Sørøst-Norge ellen.k.baskar@usn.no

\title{
Narrativ strategi
}

\author{
Nettundervisning i kunst og håndverk
}

\section{SAMMENDRAG}

Kunst- og håndverksfaget i lærerutdanningene basert på nettundervisning $i$ sanntid gir andre forutsetninger for å skape motivasjon, engasjement og deltakelse i studentgruppene. Undervisningsformen forutsetter også andre betingelser enn tradisjonell klasseroms-undervisning til å skape og opprettholde god kommunikasjon med studentene og til oppfølging av deres faglige arbeid og læring. Gjennom bruk av pedagogisk aksjonsforskning som metode i tilknytning til undervisning i to ulike studentgrupper, presenteres i denne artikkelen en undersøkelse, hvor det tas i bruk en narrativ strategi. En narrativ strategi er i denne sammenhengen en hensiktsmessig bruk av fortelling med intensjoner om å bedre det fag-didaktiske opplegget $i$ og rundt nettundervisning. Ved å innlede studieåret med å presentere studentene for ulike utfordringer og valg av løsninger knyttet til eget kunstneriske utviklings-arbeid var hensikten à utvikle en felles plattform som utgangspunkt for motivasjon til, deltakelse $i$ og kommunikasjon omkring skapende arbeid. Observasjon knyttet til de ulike fasene $i$ undervisningsforløpet viste at studentene hadde en positiv utvikling i forhold til faglig kommunikasjon og forståelse av hvordan læring knyttet til skapende arbeid henger sammen og utvikles. Jeg finner grunn til å til å knytte disse positive erfaringene til anvendelsen av narrativ strategi og drøfter dette opp mot Bruner og Bandura sine teorier om oppdagelseslæring og modellæring.

Nøkkelord:

Profesjonsutdanning, faget kunst og håndverk, nettundervisning, narrativ strategi.

\section{INNLEDNING}

\section{Lærerutdanning $\mathrm{i}$ kunst og håndverk som nettundervisning}

Universitetet i Sørøst-Norge (USN), campus Notodden, har de to siste tiårene hatt fokus på utvikling av nettundervisningstilbud innen profesjonsutdanningene. Denne utdannings-institusjonen var blant de første i landet med å tilby nettbaserte utdanninger på dette nivået, et tilbud som i ettertid har blitt betegnet som et nasjonalt pionerarbeid. Dette har senere vært attraktive studietilbud, noe blant annet tallene fra samordna opptak våren 2020 også viste. Av den totale søkermasse ved USN på 8887 s $\varnothing$ kere var 2001 av dem, det vil si nærmere 18 \% av søkerne, knyttet til nett- og samlingsbaserte studier. Disse tallene viser at de nettbaserte studietilbudene spiller en vesentlig rolle i USN sin studieportefølje. 
Resultatet av USN sitt prioriterte fokus på utvikling av så vel digital infrastruktur og digital undervisningskompetanse i personalet fikk en vesentlig betydning da Covid19-pandemien førte til nedstenging av alle norske utdanningsinstitusjoner den 12. mars 2020. Fra denne datoen ble klasseroms-undervisning byttet ut med undervisning via nettet, og vårens eksamener ble gjennomført digitalt.

Digitalisering har påvirket og endret samfunnet på mange måter. Innen utdanning har vi de siste tiårene også observert en tydelig fokusering på bruk av IKT i læringsarbeidet. Utvikling av digital kompetanse ble allerede i læreplanen LK06 (Kunnskapsdepartementet, 2006) beskrevet som en av fem grunnleggende ferdigheter for skolens virksomhet, noe som også speiles i retningslinjene for grunnskolelærerutdanningene (GLU) (Kunnskapsdepartementet, 2010a, s. 9; Kunnskapsdepartementet, $2010 \mathrm{~b}$, s. 9). Dette har utfordret lærerutdanningsinstitusjonene både på forståelse av hva grunnleggende ferdigheter er, på hvordan dette skal implementeres i utdanningstilbudene og på den faglige ansvarsfordelingen. De fem grunnleggende ferdighetene er også videreført i læreplanen Kunnskapsløftet 2020 (Kunnskapsdepartementet, 2017a). Innen UH-sektoren har krav om bruk av digital teknologi dreid seg både om en digital påvirkning av de ulike læreprosessene kvalitativt, og på å gjøre studentene godt rustet for fremtiden i et digitalt samfunn og en digitalisert skole (Kunnskapsdepartementet, 2017b). Det er et uttalt ønske fra myndighetene om $\varnothing$ kt oppmerksomhet både på bruk av digital teknologi og på utvikling av nettbaserte studier for å gjøre høyere utdanning mer tidstilpasset og tilgjengelig for flere (Kunnskapsdepartementet, 2017b; Fossland og Ramberg, 2016). Dette har over tid vært med på å utvikle et behov for endringer av etablerte lærings- og undervisningsformer (Kunnskapsdepartementet, 2017b), noe førsteamanuensis Fossland (2015) beskriver som 'den digitale vendingen' i høyere utdanning.

Allerede fra høsten 2009, har kunst og håndverk organisert som et nett- og samlings-basert studie, vært et 30 stp. videreutdanningstilbud for grunnskolelærere ved USN. I slike studier møtes studentene ukentlig til skjermbasert undervisning til oppsatte tider i det digitale klasserommet, hvor alle ser og hører hverandre. Fra 2011 har også lignende valgfagstilbud vært gjeldende for GLUstudenter. Studiet er bygd opp som en 30 studiepoenggivende enhet og består av 2 emner à 15 studiepoeng med varighet over to semestre. Her har studentgruppene bestått av både studenter med ulik campustilhørighet innen USN og studenter fra andre utdanningsinstitusjoner. I tillegg har det vært innslag av ferdig utdannede lærere som har gjennomført studiet som kompetansegivende videreutdanning. En ideell $\varnothing$ vre grense for opptak på 24 studenter har blitt satt for dette studietilbudet, noe som begrunnes i et krav om at studiet skal ha preg av aktiv og faglig toveis kommunikasjon både med faglig ansvarlig og mellom alle i gruppen som sitter geografisk spredt rundt i det ganske land.

Hovedforskjellen fra ordinær klasseromsundervisning er at undervisningen er lagt til det digitale klasserommet og foregår via en videokonferanse, hvor hver deltaker er tilstede i form av levende bilde og lyd på dataskjermene. Dette utdanningstilbudet har formelt vært bygd opp rundt 3 timers samling i gruppe, 10 uker i semesteret. I tillegg tilbys det individuell- og gruppeveiledning, både som mer uformelle frivillige veiledninger og obligatoriske veiledninger til fast avtalte tider. Hvert semester samles i tillegg studentgruppen på campus i fem sammenhengende dager til fagdager på de ulike spesialverkstedene. Disse dagene er obligatoriske og svært viktig både for studenter og lærere, for å skape gode relasjoner innad i gruppen. Emneplanene presenterer mål, læringsutbyttebeskrivelser og vurderingsformer der både struktur og ordlyd har klare referanser til de sentrale styringsdokumenter for grunnskolelærerutdanningene 1. - 7. og 5. - 10. trinn (Kunnskapsdepartementet, 2010a; Kunnskapsdepartementet, 2010b). I tillegg bygger studietilbudet på detaljert oppsatte semesterplaner som både speiler innholdet i emneplanene, konkretiserer innholdet og hvor pensumlitteraturen er hensiktsmessig innplassert. Semesterplanene er i samsvar med de lokale styringsdokumentene som utarbeides av emne-ansvarlig i samarbeid med andre ansvarlige faglærere. Høstsemesteret har innholdsmessig i stor grad hatt fokus på det todimensjonale bildeområdet, mens vårsemesteret har hatt fokus på tredimensjonale materialstudier og arbeid i materialer. De tre til fire arbeidskravene pr. 15 studiepoeng, spenner fra $\varnothing$ velser i ulike materialer og teknikker til mer omfattende problembaserte oppgaver, hvor både prosess- og produktdokumentasjon, teori og didaktisk refleksjon skal inngå som del av arbeidet. Arbeidskravene leveres som digitale mapper på universitetets læringsplattform. Faglærers tilbakemelding på arbeidskravet, studentenes egenvurdering og individuell veiledning legger til rette for 
en aktiv vurderingspraksis 'vurdering for læring' (Engh et al., 2007). Alle arbeidskravene gjennom semesteret må være godkjent før studentene får gå opp til eksamen både høst og vår. Eksamen har form av en digital mappeinnlevering, hvor studentene selv velger ut et allerede gjennomført og godkjent arbeidskrav, i tillegg velger også emneansvarlig lærer ett gjennomført og godkjent arbeidskrav som alle studentene skal levere. På denne måten åpner eksamensformen opp for en bearbeiding og forbedring av arbeidskravene. For de faglig ansvarlige har det på denne måten vært en grunnleggende strategi å ha fokus på, avdekke og vurdere kvaliteter som kan erstatte og utfordre de etablerte analoge undervisningsformene i faget.

\section{Kunst og håndverksfagets egenart}

Studiefaget kunst og håndverk innen norsk lærerutdanning er et estetisk fag som bærer i seg ulike tradisjoner, både fra håndverkenes vekt på materialtradisjoner og reproduserende arbeids-prosesser, fra designeres idéutviklings- og problemløsningsstrategier og fra kunstnerens fritt skapende arbeid satt inn i en fagdidaktisk sammenheng (Utdanningsdirektoratet, 2016). Jeg tar utgangspunkt i læreplanen for kunst og håndverk (LK-20) hvor fagets sentrale strukturer beskrives gjennom de fire 'Kjerneelementene': Håndverksferdigheter, Kunst- og design-prosesser, Visuell kommunikasjon og Kulturforståelse (Kunnskapsdepartementet, 2020).

Utvikling av praktiske ferdigheter, både i materialer og gjennom digital teknologi, er sentrale områder i undervisningen hvor estetikk inngår som vesentlige faktorer og settes i sammenheng med både faglig kunnskap og praktiske ferdigheter i en sanselig kommunikasjonsform (Austring og Sørensen, 2006 , 2019). Nettundervisningen i sanntid gir rom for sanselig kommunikasjon både visuelt og auditivt, men har samtidig begrensede muligheter for sanselig kommunikasjon knyttet til andre sanseområder. Dette søkes blant annet kompensert gjennom å vektlegge bruk av omvendt undervisning som pedagogisk prinsipp. Her kan den praktiske opplæringen presenteres i form av ulike digitale læringsressurser og benyttes som grunnlag for studiearbeidet hos den enkelte student. I arbeidskrav innenfor ulike materialområder benyttes for eksempel instruktiv film som innledning til en oppgaveperiode. Ansvaret for når og hvordan studentene benytter de digitale læringsressursene hviler i stor grad på studentene selv. I læringsarbeidet inngår også det å vurdere og skaffe tilveie materialer og verktøy på egenhånd. Kunnskap om materialer, teknikker, verktøy skaffet tilveie på denne måten gir ofte et lokalt kulturelt preg på oppgaveløsningen og kan medføre større mangfold enn for studentgrupper med campustilhørighet. I kunst og håndverk er faglige prosesser i stor grad tilknyttet individuelt arbeid, men som et fag i en profesjonsutdanning hvor målet er å bli lærer i grunnskolen, inngår fagdidaktikk i en større og videre sosiokulturell kontekst. Dette innebærer at fag, fagdidaktikk, pedagogikk og praksis skal, både innholdsmessig og organisatorisk, være tett sammenkoplet. I valgfaget kunst og håndverk tilknyttet lærerutdanningene organisert som nettundervisning, skal studentene tilegne seg kunnskap og ferdigheter innenfor et allsidig sammensatt fagfelt både analogt og digitalt. Kunst og håndverk handler slik i stor grad om handling, aktivitet og deltagelse. Utfordringen som jeg som lærer synes å ha sett en $\varnothing$ kende tendens til de siste årene handler om ubalanse mellom studentenes aktivitet og engasjement i nettklasserommet. Dette har konkret medført en $\varnothing$ kende tendens til at studentene velger å ikke være pålogget med bilde og lyd slik forutsetningene for gjennomføring av studiet krever. Studenter bak inaktive skjermbilder kan likevel se alt som foregår i det digitale klasserommet, men verken jeg som underviser eller de andre i studentgruppen vet med sikkerhet om det faktisk sitter en person bak de frosne skjermbildene.

\section{Personlig erfaring med nettundervisning}

Som lærer har jeg hele tiden opplevd det å undervise nettstudenter som både interessant og mulighetsskapende, men også utfordrende. Ut fra mine erfaringer med nettbasert undervisning i faget mener jeg over tid å ha observert en endring i studentenes tilnærming til faget. Dette har tydeligst kommet til uttrykk gjennom mindre aktivitet i samhandlingen mellom studentene og ikke minst også gjennom mindre samhandling med meg som lærer. Studentene har over tid utviklet en mer lyttende enn deltakende rolle. Samhandling og aktivitet ble lydig gjennomført når det stod på programmet, men engasjement manglet. Studentgruppene oppnådde likevel gode karakterer og fakultetets evalueringer 
viste at de fant undervisningen interessant. En grunnleggende teknisk forutsetning for å skape et aktivt læringsmiljø i det digitale klasserommet handler om at alle studentene møter til klasseundervisningen med lyd og bilde. Som lærer føltes situasjonen både enerverende og utmattende når studentene velger å sitte med inaktivt bilde. I mangel av fysisk nærvær i klasserommet begynte jeg å reflektere over mulige endringer for å redusere inntrykket av fysisk avstand. Dette resulterte i at jeg utviklet en ny strategisk tilnærming til undervisningen. Jeg vektla å ta utgangspunkt i min, det vil si lærerens, egen subjektive tilnærming til den skapende virksomheten ved å vise til både prosess og produkt fra mitt eget kunstneriske utviklingsarbeid. I formidlingen valgte jeg å vise fotografier sammen med muntlig fortelling. I nettundervisningen har denne strategien hatt en dobbel hensikt: Den har ikke bare blitt benyttet som en estetisk språkform i presentasjon av meg selv som faglærer for en ny gruppe studenter. Den har også fungert som en slags forklarende metafor fordi den i seg selv også beskriver strukturen i en skapende prosess, fra ide og ideutvikling til ferdig og kommunisert produkt.

Det er i nettklasserommet at mulighetene for faglig utdyping og meningsskaping ligger både for studentene individuelt og i samlet gruppe. Ut fra et fokus og behov om $\varnothing \mathrm{kt}$ aktivitet i nettklasserommet hvor faglig samhandling, relasjonsbygging og aktivitet står i sentrum, utviklet jeg en narrativ strategi. Med narrativ strategi menes her lærers fag-didaktiske opplegg bygd som et faglig hendelsesforløp rundt en fortelling, med en hensikt om å skape faglig forståelse og sammenheng, herunder beskrevet som faglig meningsskaping. Når vi ikke har tilgang til fysisk nærhet, verken til hverandre eller materialene i nettundervisningen, må nødvendigvis skapende og sanselig erkjennelse (embodied making and learning) formidles på annerledes vis enn i verkstedene på campus.

Gjennom en multimodal formidling, ved å vise foto og muntlig fortelling fra min egen tekstile bildeskapende prosess formidlet jeg også samspillet mellom følelser og kroppsbasert erfaring og læring. En slik form å formidle utøverens erfaringskunnskap i praksis, har likhetstrekk med videodokumentasjon slik Groth (2017) og Riis (2016) viser til i sine PHD-undersøkelser. Gjennom narrativ strategi kom jeg nærmere en kroppsforankret formidling.

Den narrative strategien i mitt prosjekt kommer til uttrykk først og fremst ved at jeg åpner for en 'ny kanal' for kommunikasjon mellom lærer og studenter i nettundervisningen. Dette skjer ved at jeg forteller åpent om eget skapende arbeid i materialer, hva som ligger til grunn for det, hva som driver det frem, hvilke utfordringer jeg møter og hvordan jeg fors $\varnothing$ ker å løse disse. Ved å vise foto fra prosessog produktarbeidet formidler jeg samtidig noe om kulturen rundt og om egne kroppsbaserte opplevelser. For det andre legger jeg til rette for at studentene selv skal kunne kjenne seg igjen i skapende arbeid ved å tolke, oppdage og gjenkalle tidligere kroppsbaserte erfaringer, men det handler også om hvordan faglig arbeid kan formidles i nettklasserommet. Denne doble prosessen handler slik om en symbolsk meningsbærende kommunikasjon mellom meg som lærer og studentene i nettundervisningen.

Narrativ strategi var ikke en bevisst strategi da jeg startet opp undervisningen i den første gruppen med nettstudenter. Mitt initiativ eller prosjekt var mer motivert av et $\varnothing$ nske om bedre kommunikasjon og en intuitiv forståelse av at det å vektlegge eget kunstnerisk utviklingsarbeid kunne bidra til dette. Forståelsen av narrativ strategi var noe som vokste fram etter som prosjektet i den første gruppen med studenter skred fram, gjennom samtaler med kolleger både innenfor og utenfor faget, gjennom teoris $\varnothing \mathrm{k}$ og ikke minst som et resultat av den relativt omfattende studieevalueringen som ble gjennomført. I denne artikkelen retter jeg oppmerksomheten mot en ny didaktisk innfallsvinkel til kunst og håndverk i nettundervisnigen som kan være med å veie opp for både mangelen av fysisk nærvær, skape rom for faglige utspill og finne andre muligheter til utforsking av materialer, redskaper og teknikker. Målet med undersøkelsen er å belyse problemstillingen:

På hvilken måte spiller narrativ strategi en rolle for faglig meningsskaping i kunst og håndverk $i$ et nettbasert studietilbud for GLU-studenter?

\section{TEORETISK RAMME}


Narrativ strategi ble utviklet for å bidra til en bedring av relasjoner mellom lærer og studenter og til økt studentaktivitet innad i nettklasserommet. Betydningen av positive relasjoner mellom lærer og student er vel dokumentert i den pedagogiske litteraturen. Hattie (2012, s. 165) fremhever betydningen av en positiv lærer/elev relasjon som en av de fremtredende suksessfaktorene for effektiv læring. I det digitale klasserommet vil nødvendigvis mange tradisjonelle virkemidler, som for eksempel umiddelbar fysisk nærhet til materialer, verktøyopplæring og sosiale opplevelser som naturlig oppstår i samlet gruppe i et fysisk klasserom nødvendigvis bli begrenset og annerledes når muligheter for ulike sanseinntrykk som lyd, lukt, romlig forståelse og taktilitet uteblir. Denne mangelen kan imidlertid invitere til refleksjon over alternative innfallsporter til å skape ulike positive relasjoner. Dette var i stor grad min opplevelse i forkant av det undervisningsarbeidet jeg skulle ta til med. I følge Bruner (1997) søker vi etter personlige strategier for å kjenne oss hjemme i verden og for å vite hvor vi skal plassere oss selv. En narrativ strategi vil $\mathrm{i}$ et slikt perspektiv ta utgangspunkt $\mathrm{i}$ fortellingen som et instrument for motivasjon og meningsdannelse. Bruner (1990) hevder at meningsdannelse skjer gjennom tolkning av hendelsene i fortellingen som derfor er middelet for å forstå det som skjer, har skjedd, eller å finne svar på hvordan det kunne skje, eller hvorfor det skjedde.

Når jeg som lærer velger en slik strategi for det første møtet med nye studenter i kunst og håndverk retter jeg oppmerksomheten mot noe som har en personlig betydning for meg, både som lærer og som skapende menneske. Dette kan være med på å synliggjøre noe, både om min identitet og om meg som fagperson og profesjons-utvikler innen lærerutdanningen (Molander \& Smedby, 2013). Eisner $(1979,2002)$ argumenterer for å vektlegge kunstneriske tilnærmingsmåter, gi plass til kunsten og den kunstneriske tenkemåten i all undervisning. På denne måten utvikles pedagogiske improvisat ører, det vil si lærere som kan forholde seg til ulike pedagogiske situasjoner og som er i stand til å benytte en rekke løsningsstrategier. Som lærere i kunstfag skal vi bidra til at elevene utvikler seg i retning av å bli kreative problemløsere mer enn tekniske roboter (Eisner, 2002). Nettundervisning i sanntid er en ny utdanningspraksis, hvor nye betydninger i tilknytning til både sosiale og historiske faglige kontekster må skapes og utvikles. I faget kunst og håndverk er kroppens betydning i skapende arbeid vektlagt, både gjennom kroppsbasert handling og erkjennelse (Groth, 2017; Gulliksen, 2017; Riis, 2016). I følge Merleau-Ponty (1994) er vi en kropp i verden, og vår forståelse av verden er et resultat av kroppslig sansning og handling. Narrativ forståelse handler ifølge både Bruner (1996, s. 21) og Polkinghorne (1988, s. 1) om meningsfylt kroppslig erfaring i tid og rom. En slik forståelse kobles mot Bruner $(1970,1997)$ sin teori om oppdagelseslæring, en teori som blant annet bygger på at meningsdanning består i å være aktiv ved å oppdage gjennom observasjon og gjennom sammenligning ved aktiv leting etter likheter og forskjeller (1970). Oppdagelseslæring inngår i et større læringskonsept kalt spirallæring (Bruner, 1960). Spiralprinsippet dreier seg om å sirkulere gjentatte ganger til fagets grunnleggende ideer, for å skape mening og utvikle sammenhenger (Bruner, 1970, s. 86-89). Denne formen vektlegger og forutsetter selvstendighet for egen læring gjennom aktiviserende undervisningsmetoder (Bruner, 1997, s. 33), slik også er tilfelle i nettundervisningen som stiller andre krav til studentenes motivasjon og engasjement. Bandura legger stor vekt på mestringstro (Self-Efficacy) gjennom det kompetente selv (Kähler, 2012). For å bygge mestringstro er iakttagelsen av rollemodeller vesentlig, denne teorien kalte Bandura (1977) modellæring. Som et eksempel på modellæring bruker han beskrivelsen av en person som skal lære å kjøre bil og skildrer denne prosessen som en kompleks og vanskelig handling hvis vedkommende aldri hadde sett en annen person kjøre bil (Bandura, 1962, s. 212). En slik kompetanse kalte Bandura 'stedfortredende' eller 'vikarierende' forsterkning (1962). Både Bruner (Aukrust, 1996) og Bandura (Kähler, 2012) forfekter sosial konstruktivisme som kunnskapsteoretisk posisjon. Et slikt læringssyn innebærer ideen om at tilegnelse og utvikling av kunnskap sees på som den enkeltes konstruksjon i samspill med andre.

\section{INNLEDENDE NARRATIV}

I innledende narrativ viste jeg foto fra min egen skapende tekstile bildeprosess, samtidig med at jeg fremførte en verbal fortelling. Selve formidlingen varte i mindre enn 15 minutter. Helhetlig en presentasjon med tydelig og mest vekt på å synliggjøre meg selv som et skapende menneske. Jeg tok 
utgangspunkt i eget kunstnerisk forsknings og utviklingsarbeid utviklet våren 2012 med tema Didaktiske visualiseringer $\mathrm{i}$ arbeid med tekstile materialer og digital teknologi. Utviklingsarbeidet hadde sitt utgangspunkt i en humoristisk middelalderballade i tradisjon fra Telemark, og resulterte i en tekstil bildeserie, som fikk samme navn som balladen «Ramnebryllup i Kråkelund» (Universitetet i Oslo, 2014). Den tekniske delen av arbeidet var en videreføring av erfaringene fra eget skapende arbeid i tilknytning med mastergraden Når det tekstile møter det digitale: Unders $\varnothing$ kelser gjennom eget og studenters skapende arbeid (Baskår, 2006). I presentasjonen av meg selv som lærer for en ny gruppe med nettstudenter byttet jeg nå ut en formell presentasjon av meg selv. I stedet valgte jeg heller å presentere meg selv som et skapende menneske, gjennom både prosess- og produktfoto vist som heldekkende bilder på skjermen, ved siden av muntlig fortelling i det digitale klasserommet. Herunder gjengis denne presentasjonen:

Helt fra barndommen har brodering og stingsetting med nål og tråd på ulike typer tekstiler vært en viktig del av meg som skapende menneske. Utvikling av tekstile bilder var tidlig en del av denne aktiviteten, jeg tegna bilder med nål og tråd. I voksen alder skjedde det en endring da jeg for femten år siden gikk til anskaffelse av en symaskin med en allsidig digital broderienhet. Dette åpnet opp for nye veier og muligheter i utviklingen av tekstile bilder.

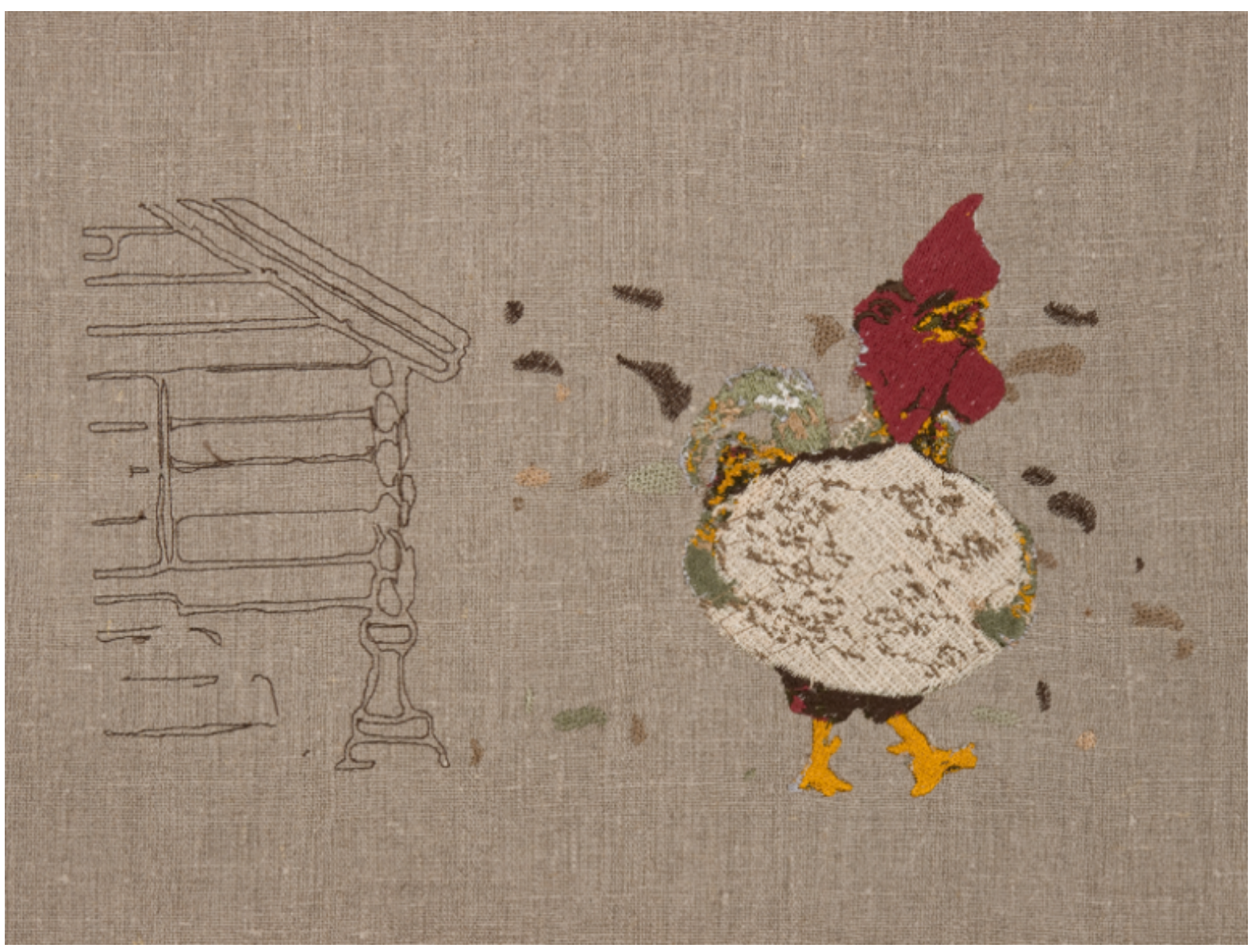

BILDE 1 Digitalt stingsatt tekstilt bilde: Den stolte hanen som stjal en flatbrødleiv.

På skjermen framfor dere (bilde 1) ser dere ett av mine tekstile uttrykk som forestiller den stolte hanen som 'spente og sparka og gjorde seg te og gol et kurkeliku' etter å ha vært på stabburet og stjålet 'ein flatbraudleiv'. Hvilket formål flatbrødet hadde skjønner dere nok av sammenhengen etterhvert, men først skal jeg fortelle om utviklingen av disse tekstile bildene. 
Inspirasjon til innhold og form hentes ofte fra et personlig, livslangt og nært forhold til rim, regler, legender, ballader og folkeviser. Dette materialet og de estetiske opplevelsene det har gitt meg, også gjennom sanglige presentasjoner, har vært viktig råstoff for min fantasiverden, et verdifullt idegrunnlag for utviklingen av så vel innhold som form også av ulike tekstile bilder. Innledningsvis i den skapende prosessen dreier det seg om å mane fram et usensurert mangfold av indre forestillingsbilder, dette er et viktig utgangspunkt for den videre utviklingen av bildeuttrykkene. Bildene vokser slik fram av ulike tankeprosesser på veien fra en vag og tenkt ide, fra ulike skisseprosesser og utprøvinger av materialer og teknikker til ferdig uttrykk. I alle deler av den skapende prosessen finner jeg spenningen og drivet jeg trenger for å bringe bildeprosessen framover. Denne bildefortellingen er en måte å formidle en slik prosess hvor utgangspunktet er å finne i den humoristiske middelalderballaden med navn 'Ramne-bryllup i Kråkelund'. Innholdet handler om en bryllupsfest der menneskene er erstattet av ulike dyrefigurer som 'spiller' ulike personer. Skogens dyr har forskjellige oppgaver i bryllupet og de ulike husdyrene er gjester som bringer med seg nokså parodiske gaver til brudeparet. Her ser dere (bilde 2) geita som hadde med seg ost, brød og masse annen forskjellig god mat. Geita er kjent for 'å gjør reint bord' og derav fått kallenavnet 'boreslikkar'.

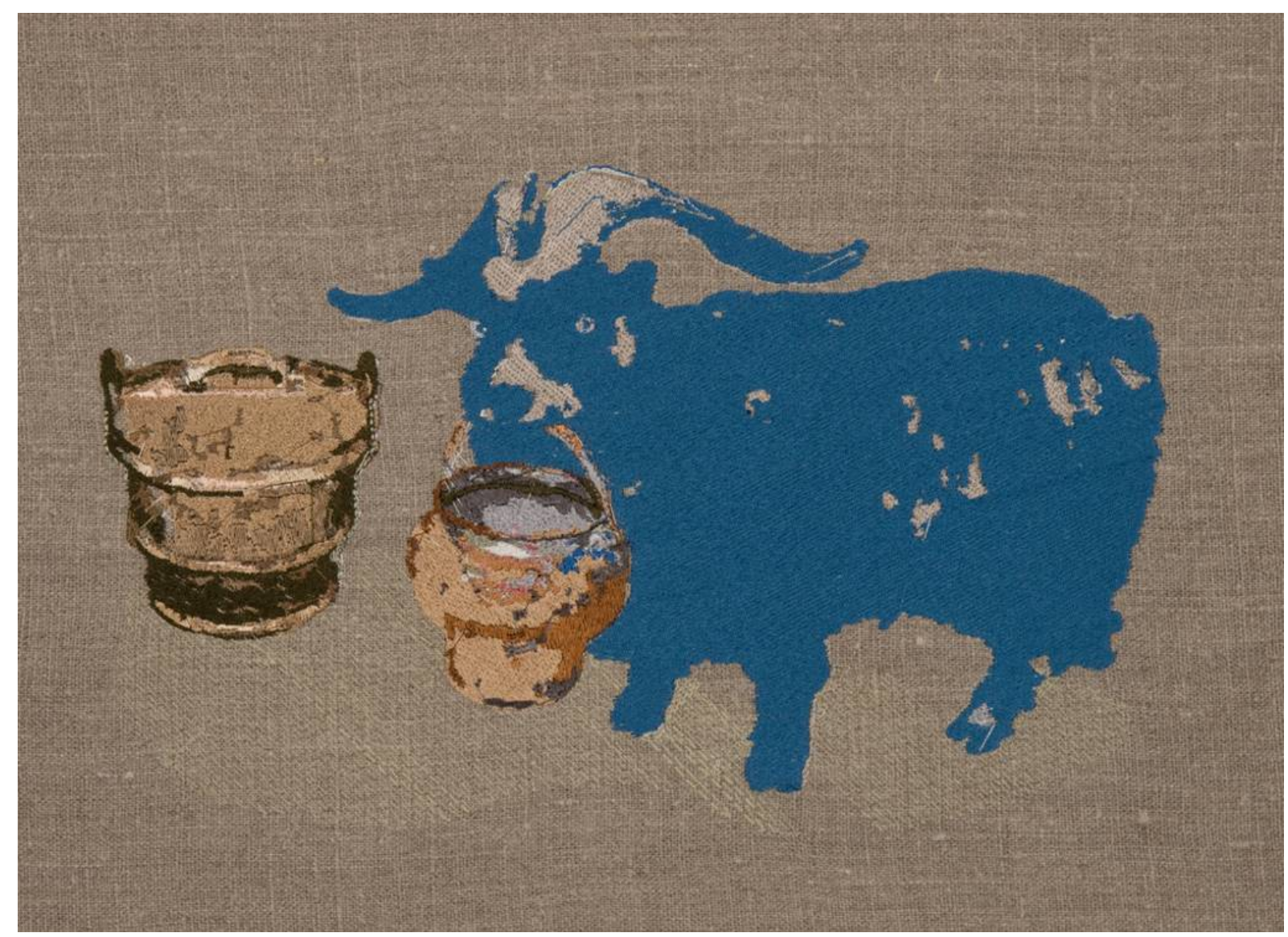

BILDE 2 Digitalt stingsatt tekstilt bilde: Geita som hadde med seg mye forskjellig god mat.

Det er usikkert om bjørnen (bilde 3) kom seg til bryllupet. For å komme dit måtte han svømme over fjorden, forfengelig som han er ville det vært ydmykende å ankomme bryllupet våt i pelsen. I bilde 4 ser dere brudeparet, den hvite slanke tranen som brud og den lille keitete sorte ravnen som brudgom. Her går de innover i kråkelunden på vei til eget bryllup. 


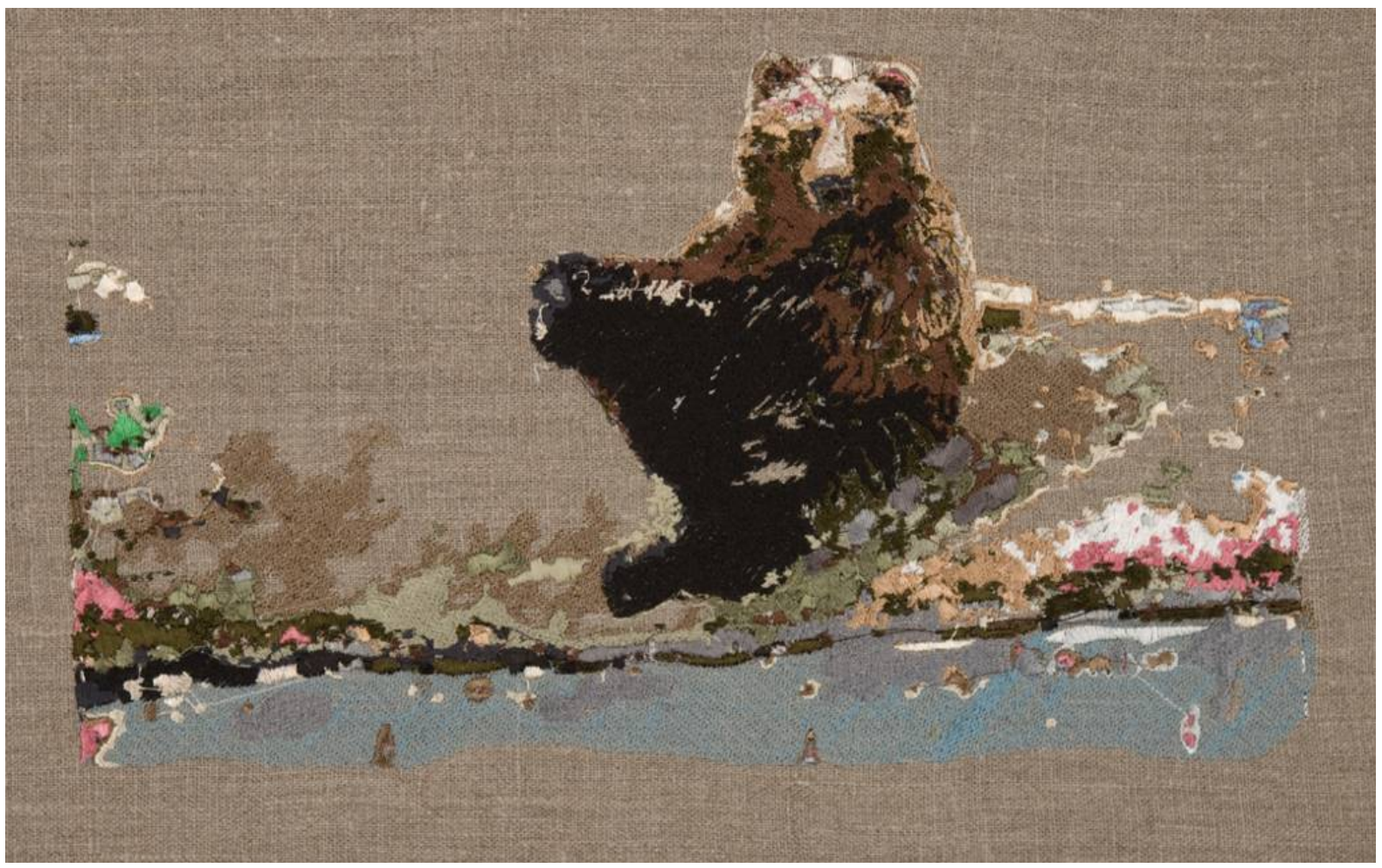

BILDE 3 Digitalt stingsatt tekstilt bilde: Den forfengelige bjørnen som ikke ville bli våt i pelsen.

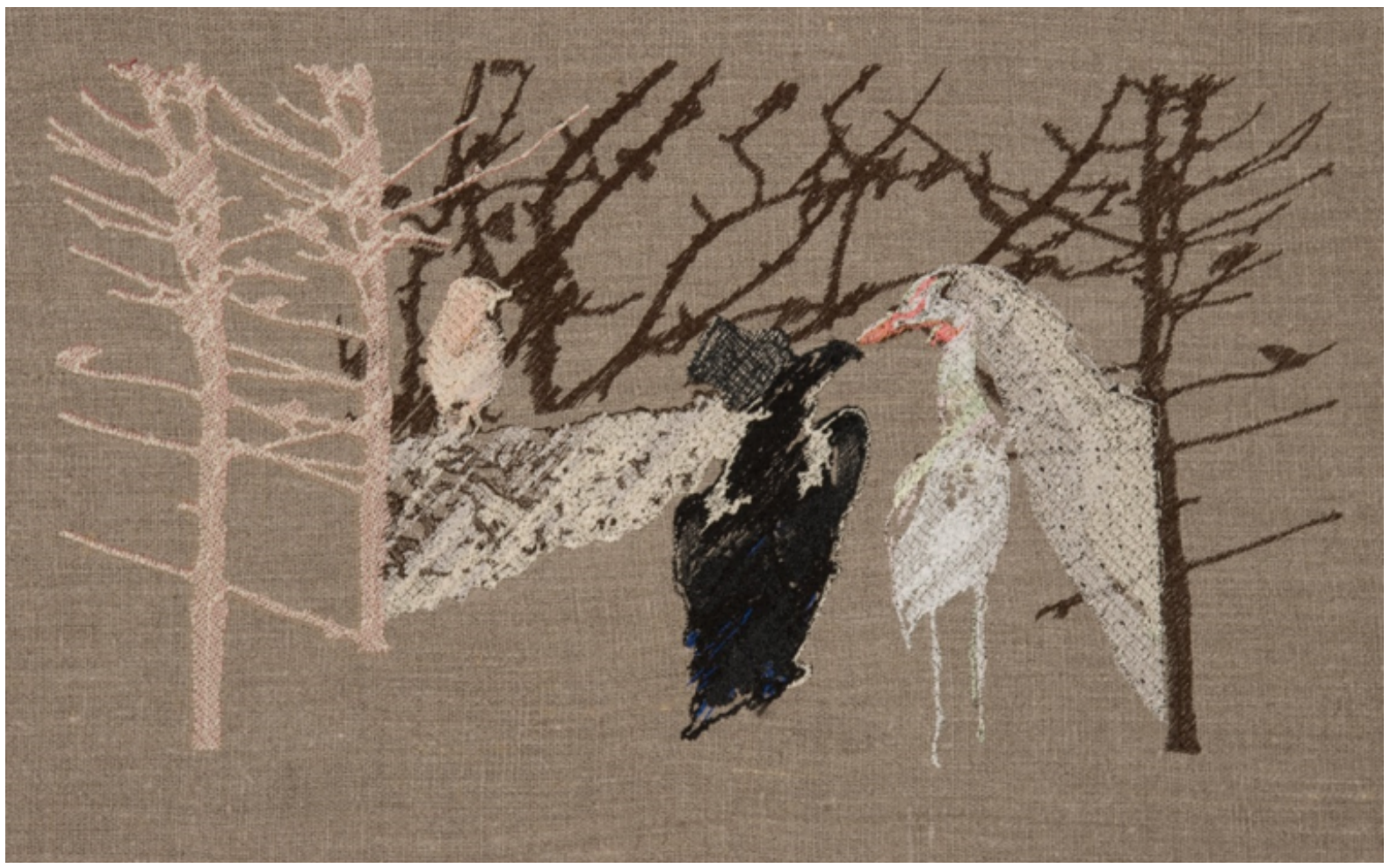

BILDE 4 Digitalt stingsatt tekstilt bilde: Brudeparet på vei til eget bryllup i kråkelunden. 


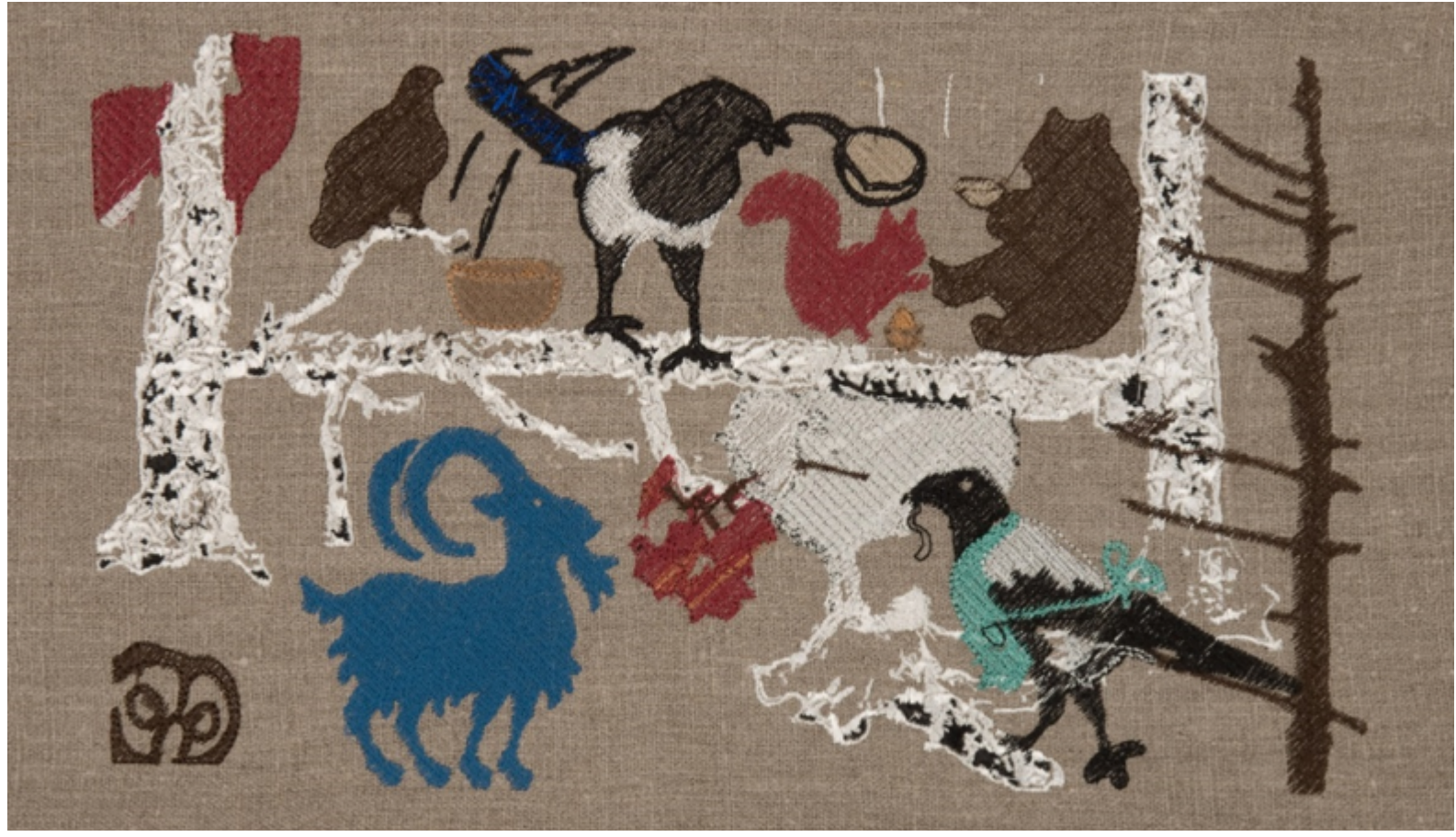

BILDE 5 Digitalt stingsatt tekstilt bilde: Noen av gjestene på bryllupsfesten.

Her (bilde 5) er noen av bryllupsgjestene som er ankommet bryllupsfesten. Kråka har fått oppgave som tjenestejente og skjæra som 'øl-skjenker'.

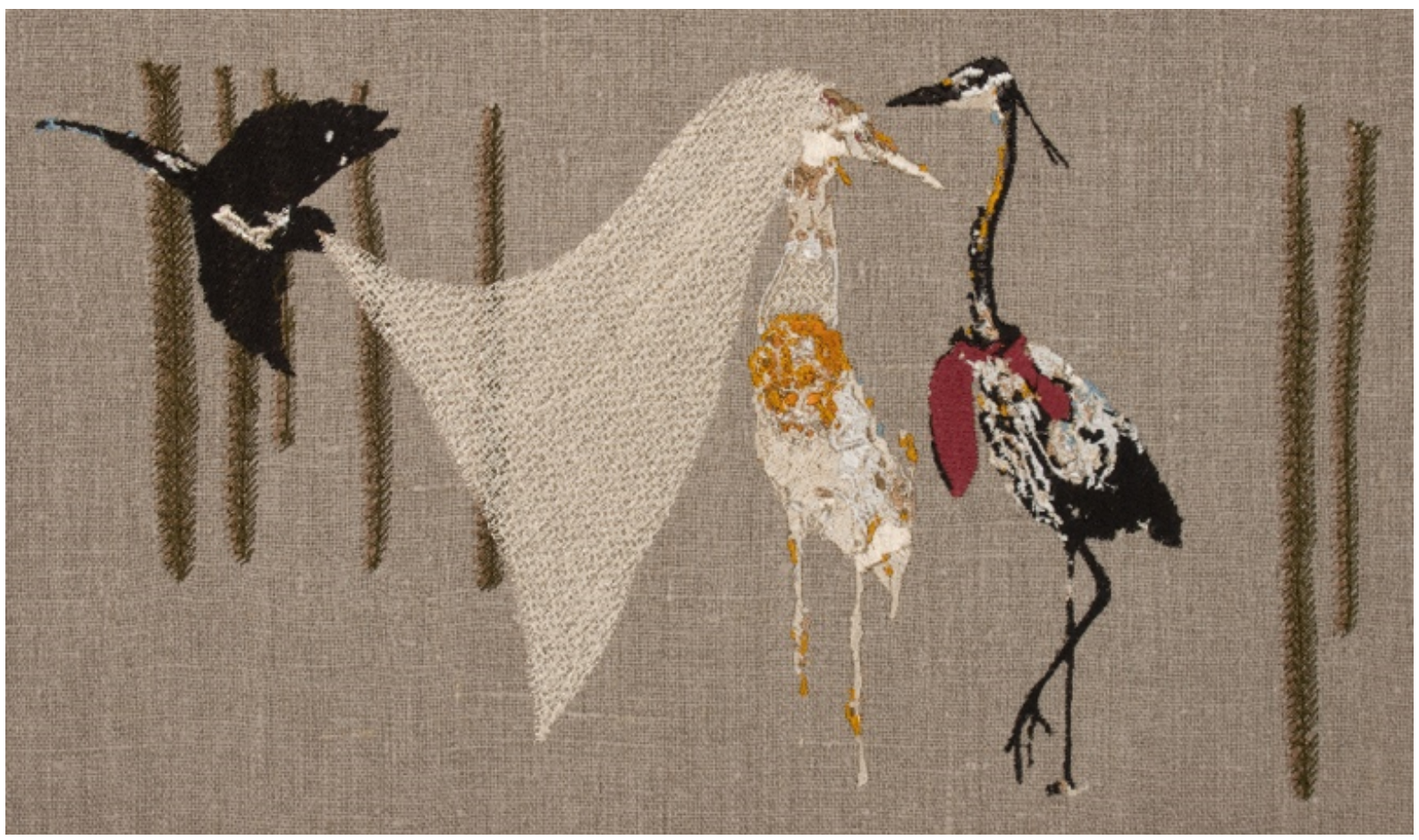

BILDE 6 Digitalt stingsatt tekstilt bilde: Bruden som blir ført til alters av hegren.

Over (bilde 6) er selve vielsen. Det var hegren som fulgte bruden til alters, mens svala 'va brurepiga $i$ skoje'. Bildeserien teller totalt 9 tekstile bilder. Felles for alle bildene er at de er stingsatt med digital symaskin på et bunntekstil av Baskerlin, som er en blandings-kvalitet av ubleket bomull og lin. I sting- 
settingen er det brukt ulike trådkvaliteter, mest silke og bomull, men også noe polyester. Hvert bilde måler ca. $40 \mathrm{~cm} \times 60 \mathrm{~cm}$.

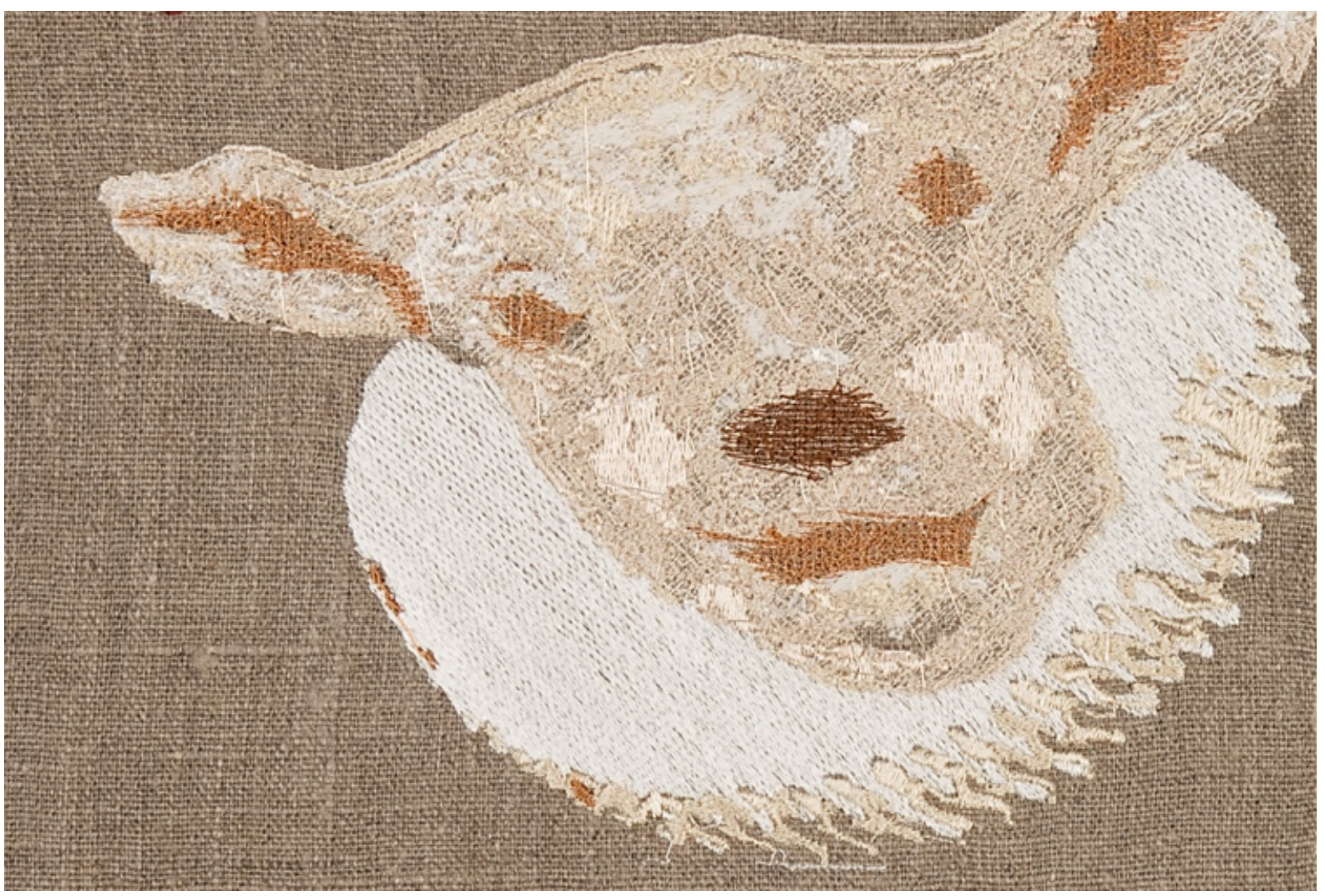

BILDE 7. Digitalt stingsatt tekstilt bilde: Sauen som var prest i bryllupet.

Sauen var prest i bryllupet, dette (bilde 7) er en detalj av det tekstile bildet som jeg har valgt ut for å synliggjøre alle de variasjons-mulighetene som kan oppstå gjennom bruk av ulike tråd-kvaliteter som for eksempel tykkelse og hvithet. Sytrådene som er benyttet er hovedsakelig i forskjellige hvit-nyanser og tykkelser og med både matt og blank tråd som gir ulike uttrykk og variasjonsmuligheter i flaten. Samme effekt vil all bruk av tråd med samme farge og i ulike kvaliteter ha på uttrykket. Et annet eksempel som konkretiserer dette ytterligere er bildet av disse trådsnellene (bilde 8 som alle viser forskjellige hvitnyanser og kvaliteter av sytråd.

På grunn av et begrenset utvalg av egnede materialer lokalt søker jeg ofte etter å finne egnede stofftyper og tråd-kvaliteter på nettet. Det er utfordrende å forestille seg kvaliteter og kvalitetsforskjeller via skjermbilder uten å kunne oppsøke materialene taktilt, eller bruke 'kjærringfingrunn' som noen kaller det lokalt. Utfordringer på det materialmessige området i arbeidet med tekstile bilder har samlet sett dreid seg om å finne egnede materialkvaliteter sett i sammenheng med ulike estetiske vurderinger omkring ønsket uttrykk.

I bilde 9 ser dere hvordan selve stingsettingsprosessen foregår. For å utvikle de tekstile bildene som jeg har vist dere, benytter jeg digitale hjelpemidler som digital symaskin med en tilhørende broderienhet. For å håndtere broderiprogrammet og for å arbeide med bildebehandling underveis $\mathrm{i}$ prosessen, benytter jeg i tillegg to datamaskiner. 

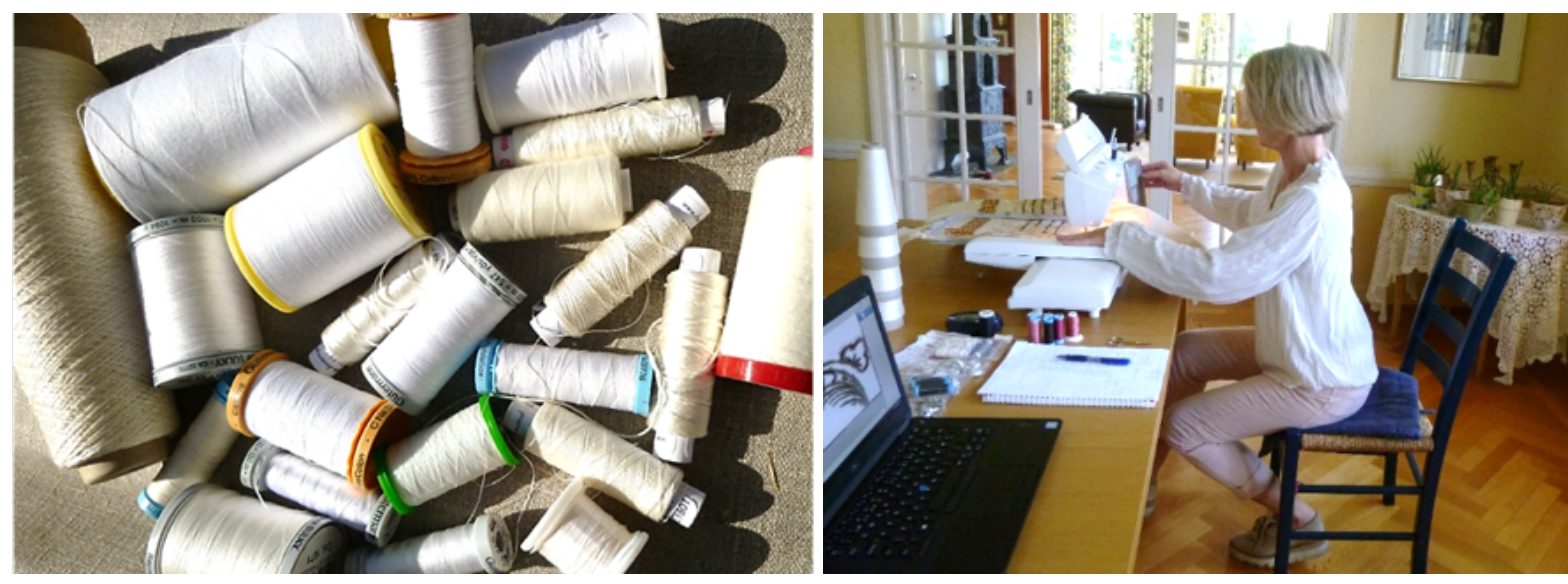

BILDE 8 og 9. Ulike sytrådkvaliteter og hvitnyanser (Bilde 8). Digitale og materielle hjelpemidler (Bilde 9).

Når bildeskissene er bearbeidet i den digitale programvaren prøves det planlagte digitale designet ut gjennom å stingsette bildet med den digitale symaskinen. I dette fotografiet (bilde 10) kan dere se hvordan bildene henges opp på ei snor for å lettere kunne studere kvalitetene i bildedesignene, så som former, stingtetthet, stinglengder, farger, trådfester og lignede fungerer. I denne prosessen blir ønskete forandringer skrevet ned i en notatbok og justeringer utføres i tråd med notatene, det må ofte flere justeringer til $f \varnothing r$ designet blir slik jeg $\varnothing n s k e r$, også det en arbeidskrevende og lang prosess. Dette materialet danner sammen med skriftlige notater en prosessdokumentasjon som har en nyttefunksjon i sammenheng med utvikling av andre bilder, hvor deler av designet kan gjenbrukes $\mathrm{i}$ helt andre sammenhenger. I slike digitale stingsettingsprosesser har baksiden eller vranga, som dere ser i dette fotoet (bilde 11) også en uttrykkskvalitet som er med i vurderingen i prosess-sammenhengen. I denne delen av arbeidet ligger det mye teknisk informasjon.
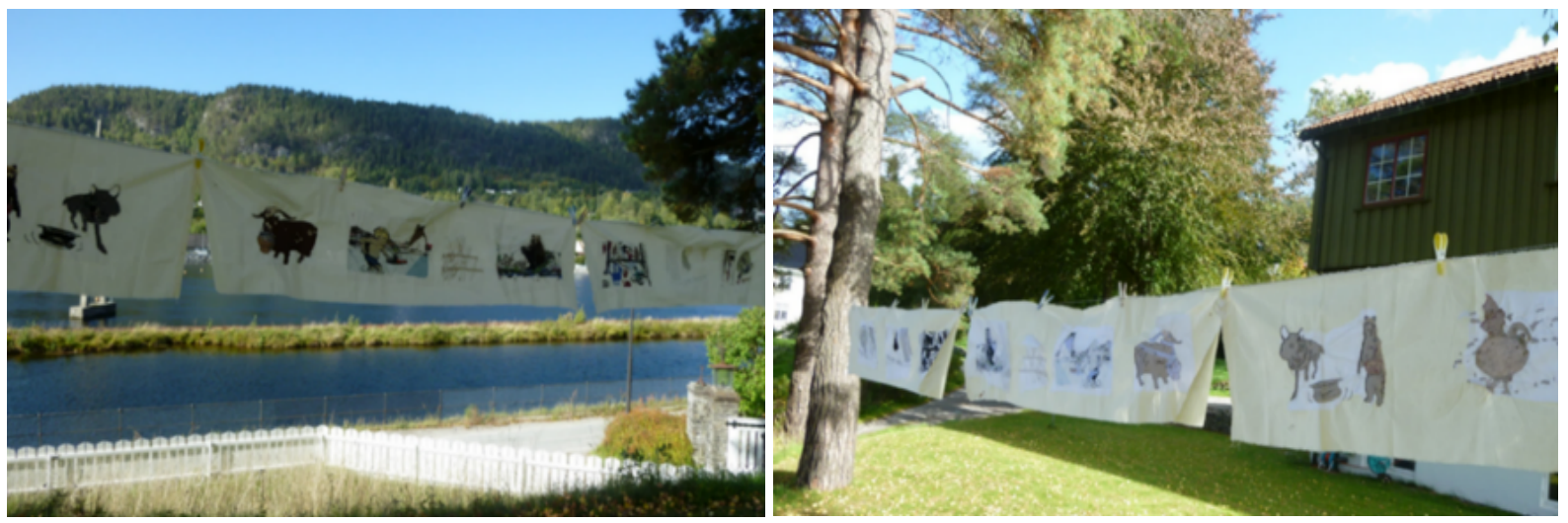

BILDE 10 og 11. Utprøving av digitalt og materielt design. (Bilde 10) Baksidens uttrykkskvalitet. (Bilde 11)

En viktig del av den skapende prosessen er å presentere bildeuttrykkene i en fysisk romlig presentasjonsform som en utstilling. Her (bilde 12) ser dere fra utstillingen Tekstile fortellinger 2012, hvor denne tekstile bildeserien ble presentert. 


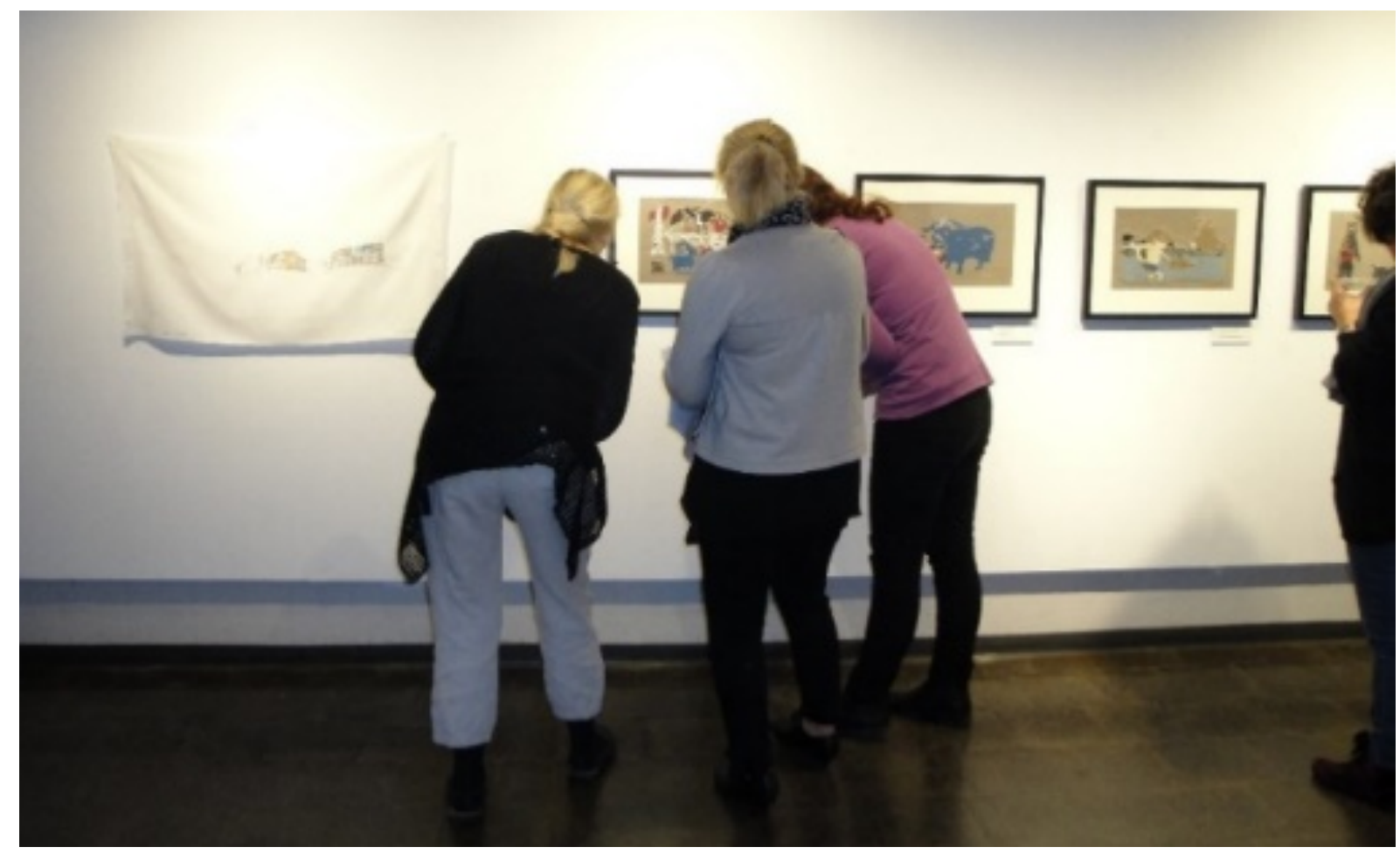

BILDE 12 Fra utstillingen i Foajegalleriet på Notodden.

Avslutningsvis vil jeg ta dere med tilbake til bryllupsfesten i Kråkelund. 'Jo-da', og selvfølgelig hadde dette bryllupet, slik vanlig var i gamle dager, også et realt slagsmål, her (bilde 13) mellom ulven og bjørnebinna. Ulven ble så sint at han 'slengde sylvarskål mot golv' binna er som dere ser utstyrt med dameveske, som er et undervurdert våpen i bryllupssammenheng.

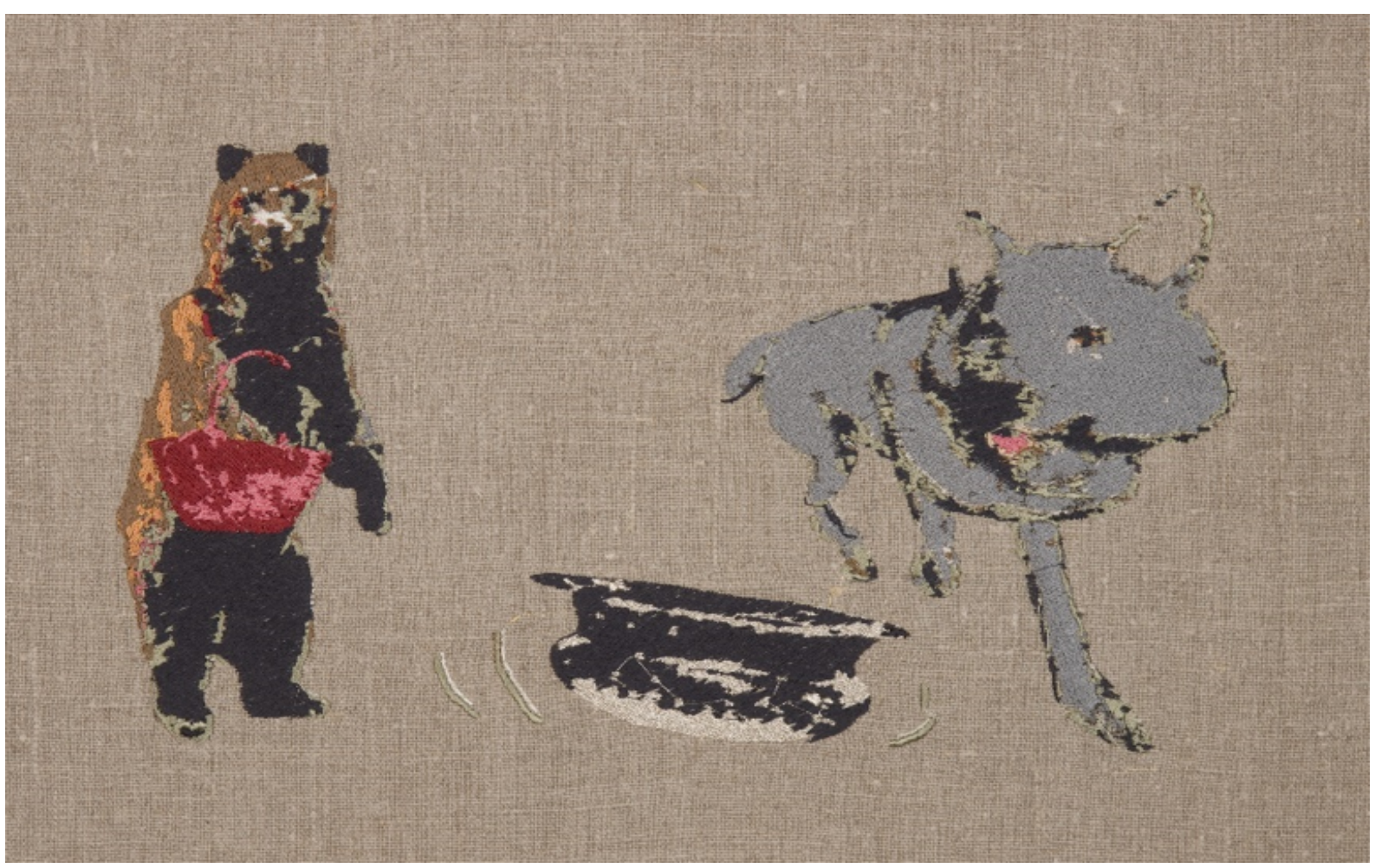

BILDE 13. Digitalt stingsatt tekstilt bilde: Bjørnebinna og ulven som sloss i bryllupet. 


\section{OPPSUMMERENDE FORELESNING}

I etterkant av innledende narrativ forsøkte jeg å tydeliggjøre prosessen for studentene ved å peke ut noen strategiske verdier og valg jeg hadde håndtert gjennom prosessen. Disse kan sies å ha en relativt generell karakter i den forstand at de er aktuelle for skapende arbeid som ivaretar prosessen fra ide til ferdig kommunisert form, og slik også for mange av de arbeidene studentene skulle i gang med. I fortettet form dreier det seg om følgende:

Presentasjonen: for å presentere meg selv som et skapende menneske benyttet jeg et estetisksymbolsk språk i tråd med Austring og Sørensen $(2006,2019)$. Innledende narrativ er basert på en muntlig fortelling som sammen med fotografier av mitt tekstile bildearbeid søker å representere min subjektivitet i arbeidet, som en sansende tilstedeværende kropp i et miljø. Prosess og produktfotografiene er små, selvstendige fortellinger som introduseres gjennom presentasjonen.

Lærers subjektive fortelling om sitt forhold til skapende arbeid: her tok jeg utgangspunkt i min livslange utvikling med ulike broderiformer og hvordan jeg fra barneårene og gjennom livet har benyttet nål og tråd på ulike vis, noe som har blitt en viktig del av min identitet og min formkultur.

Inspirasjonsmateriale: handler om hvordan jeg usensurert maner frem ulike forestillingsbilder og leker med dem i fantasien og setter disse sammen til nye bilder og i nye sammenhenger.

Ideutvikling: handler om skapende arbeid og idefasens grunnleggende viktighet hvor alle Iøsninger er mulige og ingenting umulig. Som viktig del i denne fasen er erkjennelsen og verdien av det å forholde seg undrende, nysgjerrig og søkende, å snu alle steiner på vei mot en mulig løsning.

Utvalg og vurdering: dreier seg her om å velge, prøve ut, omforme, realisere og om å kommunisere i jakten på en sansbar form, et uttrykk.

Materialer og teknikker: dreier seg om valg av virkemidler som materialer og teknikker og utprøvinger og vurderinger av kvaliteter.

Fra skisser til ferdig design: dreier seg om gangen fra skisser, arbeidstegninger og ulike utprøvinger til ferdig design. Denne fasen er knyttet til den strukturerte planleggingen modellutformingen og utkast som vurderes og velges helt til det best mulig tilfredsstiller den impulsen og de forestillingene som satte handlingen i gang. I dette arbeidet skapes den sansbare formen.

Utvikling av tekstile bilder med digital symaskin: dreier seg om justeringer av alle detaljer som må være på plass før bildets design er klargjort for brodering. Prosessdokumentasjon i form av skriftlige notater omkring fagerkoder, kvaliteter og stinginformasjon har en nyttefunksjon i sammenheng med at bildet kan redesignes og benyttes i andre og nye sammenhenger.

Utstilling og formidling: er en viktig del av en skapende prosess som handler om å presentere bildeuttrykkene i en fysisk romlig presentasjonsform som en utstilling.

\section{FORSKNINGSSTRATEGI: PEDAGOGISK AKSJONSFORSKNING}

Undersøkelsen i denne artikkelen er basert på en kvalitativ tilnærming som innebærer et nært samarbeid mellom lærer som forsker og studentene som forskningsdeltakere. Forskningen som gjennomføres i undervisningen sammen med studentene er inspirert av den praktiske pedagogiske aksjonsforskningstradisjonen, også kalt lærerforskning eller pedagogisk aksjonsforskning. Aksjonsforskning i pedagogiske kontekster begrunnes først og fremst i viktigheten av at lærere selv medvirker til å utvikle profesjonskunnskap, både for den enkelte lærer og for selve profesjonen (Carr \& Kemmis, 1986; Elliott, 1991; Hiim, 2010, 2013; Kemmis, 2001; Stenhouse, 1975; Whitehead \& McNiff, 2006). Det spesielle for denne innfallsvinkelen til aksjonsforskning er ifølge Zeichner (2002) relasjonen til praktisk-teoretisk didaktikk hvor systematisk bruk av didaktiske begreper i refleksjon over undervisning og læring sees som grunnleggende. I undersøkelsen som denne artikkelen omhandler, handlet det om å utvikle forståelse av praksis og videre endre situasjonen som handlingen eller praksisen foregår i. Pedagogisk aksjonsforskning ivaretar nettopp en slik tilnærming hvor innsikt i å stille spørsmål til egen praksis og å fokusere på de faktiske oppgavene som læreren har i sitt arbeid anerkjennes. Tanker og ideer blir på denne måten forent med utdanningsfeltet både gjennom utprøving i undervisningen, refleksjoner rundt og sammen med teori innenfor rammene i lærerutdanningen. Spørsmål inspirert av Hiim (2010) og Whitehead og McNiff (2006) er vektlagt for å ivareta validitet i 
denne aksjonsforskningen. Spørsmålene dreide seg om: Hvilke erfaringer og opplevelser bør beskrives for å vise hva som har skjedd? Hvilke data viser utviklingen som har skjedd? Hvordan kan en beskrive og evaluere funnene i og av lærings-prosessen?

Narrativ strategi er aksjonen i denne undersøkelsen og retter slik oppmerksomheten mot denne handlingens påvirkning i nettundervisningen i kunst og håndverk tilknyttet GLU. Handlingen er en søken etter nye måter å ta i bruk faglig undervisningsmateriell for å bedre aktivitet, samhandling og interaksjon mellom studentene og meg som lærer i nettklasserommet. Aksjonen innledningsvis til studieåret som jeg kalte 'innledende narrativ' er et fagdidaktisk opplegg som er utviklet omkring 'min fortelling og min strategi' formidlet gjennom et estetisk symbolsk språk med et siktemål om å oppnå en mer tilrettelagt undervisning for kommunikasjon og samhandling i nettklasserommet. Narrativ strategi handler om en lærers presentasjon av seg selv i det første møte med studentene i nettundervisningen ved innledningen til studieåret. Fra lærerhold har det vært vanlig å presentere seg selv mest knyttet til formell faktainformasjon. Her valgte jeg denne gangen en presentasjonsform i et estetisk og symbolsk språk.

For å finne svar på problemstillingen, har jeg innhentet og analysert observasjons-materiale fra to observasjoner i to ulike studentgrupper i kunst og håndverk, GLU. Gjennom årene har det variert noe hvilket år valgfaget kunst og håndverk har vært innplassert i GLU. alle studentene i undersøkelsen har hatt grunnleggende kjennskap til studentrollen, men i varierende grad om det å være nettstudent. Utvalget av studentgruppene hadde til felles at de utelukkende bestod av kvinner, gjennomsnittsalderen var på mer enn 30 år og de var bosatt i ulike deler av landet. Begge gruppene var sammensatt av studenter fra ulike GLU-klasser og trinn, både fra USN og fra andre utdanningsinstitusjoner. Ingen av studentene hadde formell utdanning i kunst og håndverk fra tidligere, noen få hadde i begrenset grad noe fagrelatert erfaring fra folkehøyskole og vikararbeid i barnehage og skole.

Mine ansvarsområder i gruppene var knyttet til gjennomgående emneansvar i semesteret og til undervisning i 5 økter à 3 timer i nettklasserommet. I tillegg hadde jeg også ansvaret for deler av verkstedsundervisningen på campussamlingen. Gruppe 1, som bestod av 19 studenter, skulle starte opp med emnet 'Håndverk, design, skulptur og entreprenørskap' (15 stp.). Arbeidskravet omfattet ide- og produktutvikling innenfor enkel veskedesign, hvor både teknikkene pappvev, grindvev og allsidig erfart kunnskap om og bruk av ulike trådkvaliteter var sentrale kravspesifikasjoner. Gruppe 2, bestod av 15 studenter som skulle starte opp med emnet 'Bilde, grafisk design og visuell kommunikasjon'. Arbeidskravet for disse studentene omfattet ide- og produktutvikling, innenfor området grafisk design, nærmere bestemt utvikling av et bokomslag tilpasset målgruppen barn. Begge studentgruppene ble introdusert for mitt innledende narrativ som første møte med meg som lærer og som første møte med semesteret. Gruppe 1 gjennomførte arbeidskravet i vårsemesteret, mens gruppe 2 gjennomførte arbeidskravet i det påfølgende høstsemesteret. I arbeidet med gruppe 1 erfarte jeg utover i semesteret at min forståelse omkring bruk av narrativ strategi vokste gradvis frem. Dette betydde at jeg hadde viktige erfaringer da jeg startet unders $\varnothing$ kelsen i gruppe 2 . Strategien fikk slik et tydeligere og mer bevisst fokus i arbeidet med gruppe 2, enn hva tilfelle var i arbeidet med gruppe 1 . Unders $\varnothing$ kelsene er av de ovenfor nevnte årsaker ikke identiske, men følger i hovedsak samme mal. For å gi et klarest og best mulig bilde av undersøkelsene, og fordi utvikling over tid var et poeng, mente jeg det var mest hensiktsmessig at utvalget knyttet seg til en av gruppene. Datagrunnlaget er hentet fra gruppe 2, som var mest helhetlig i formen og derfor best egnet som grunnlag for analysearbeidet. Her kunne jeg også bygge observasjonsarbeidet på erfaringer jeg hadde hentet inn i arbeidet med gruppe 1. Datainnsamlingen tok først og fremst utgangspunkt i aktiviteten i det digitale klasserommet, men omfattet også empiri fra den fysiske samlingen på campus. Dette valget ble gjort fordi samlinger er en naturlig del av og kjennetegner nettundervisningens form (Fossland, 2015).

Miljøet og rammene for unders $\varnothing$ kelsen tilknyttet nettklasserommet kan best beskrives som et begrenset sanselig miljø. Gjennomføringen av denne delen av unders $\varnothing$ kelsen tok slik utgangspunkt i en visuell og auditiv observasjon i tilknytning til det som skjer i video-konferansen på dataskjermen. Dataskjermen kan visuelt deles inn i tre hovedfelt: bildene av studentene, chattefeltet og skrivebordet. Innredningen med bilder og chattefelt er fleksible og kan flyttes og innredes etter eget $\varnothing$ nske. Bildene av studentene og lærer er ikke større enn en fyrstikkeske og gir bare plass til hode og i begrenset grad 
noe av det fysiske miljøet rundt. Alle i det digitale klasserommet ser det samme, men de ulike delene kan organiseres etter eget $\varnothing$ nske.

I aksjonsforsknings-prosessen tok jeg i bruk et observasjonsskjema for å dokumentere, et A3 ark for hver time. Skjemaet ble delt i tre felt, hvor det ene feltet viste beskrivelser, det andre feltet umiddelbare tanker, spørsmål og tolkinger og det tredje feltet var viet beskrivende mindre skisser og symboler som hjalp meg å huske sammenhenger. I prinsippet lignet dette på Postholm og Moens (2018, s. 56) beskrivelser av observasjonsnotater til bruk i aksjons-forskning. Observasjonsskjemaet hadde jeg plassert ved siden av tastaturet og skrev for hånd uten å ta blikket vekk fra studentene på skjermen. Selve observasjonsprosessen knyttet til dataskjermens skrivebord ble dermed svært oversiktlig. I undervisningen knyttet til samlingen på campus kom jeg tett på studentene, både den fysiske og sosiale verden sånn som den 'viser seg for meg direkte' (Vedeler, 2000). I verkstedet måtte jeg bevisst sette av tid for å danne meg oversiktsbilder av situasjonene og for å foreta observasjonsnedtegnelser. Dokumentasjonen fra både nettundervisningen og undervisningen på campus, viser prosessen av registreringer og gjengivelser av dataene som har vært utgangspunktet for refleksjonene rundt hvilken påvirkning narrativ strategi har hatt i kunst og håndverksundervisningen i tilknyttet lærerutdanningen GLU.

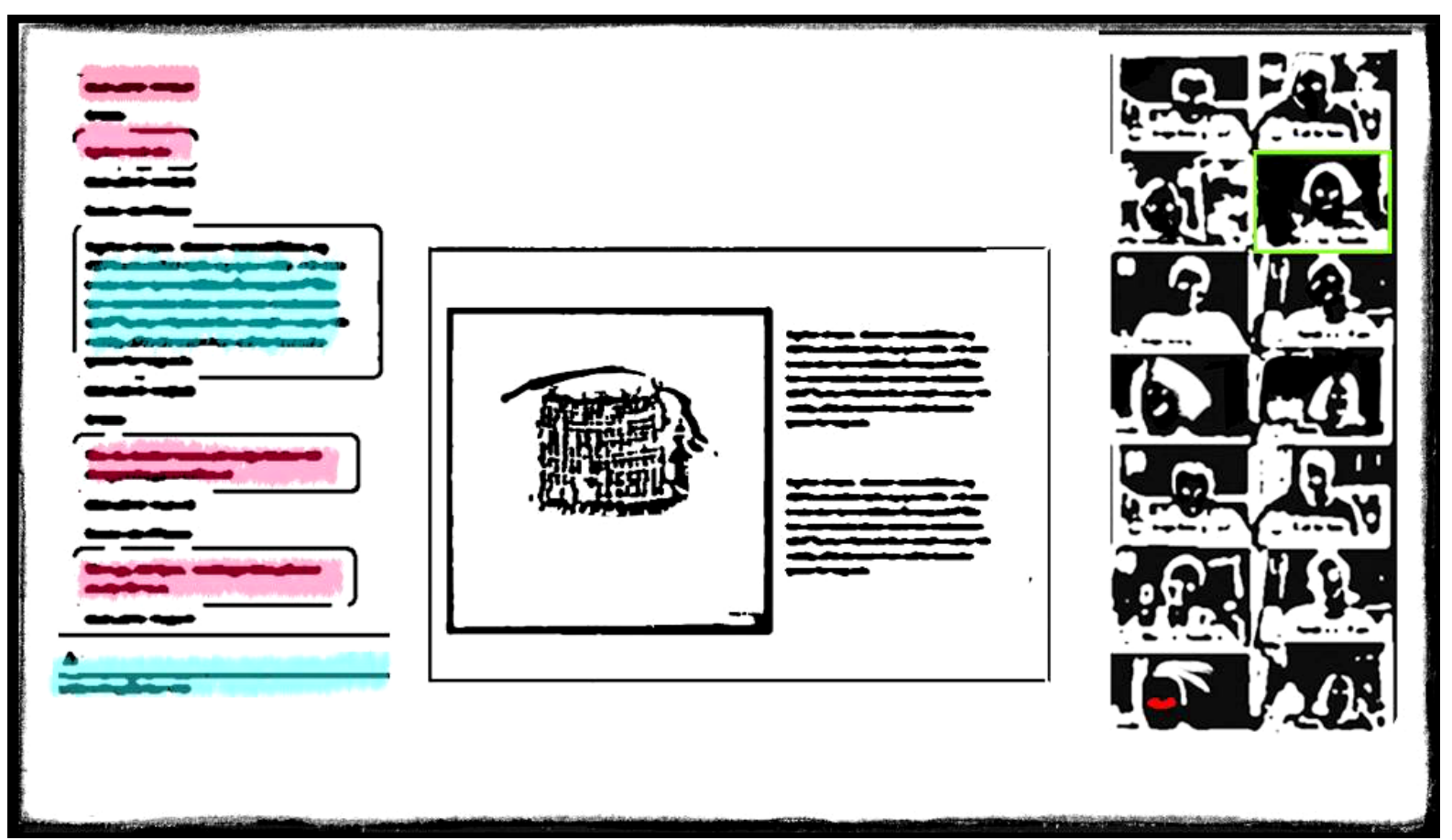

BILDE 14. Illustrasjon av nettklasserommet, slik jeg liker å organisere det.

Studentene i klassene ble informert om forskningsprosessen, om min rolle som lærerforsker og at deres status i prosjektet var medforskere. De ble videre informert om opplegget slik at de var oppdatert på hva jeg hadde gjort og hva jeg kom til å gjøre. Studentene var informert om at de når som helst kunne gi beskjed dersom de ikke ville delta videre. Dataene som jeg samlet fra undervisningen, var generelle og observasjonene ble ikke på noe tidspunkt nedtegnet med navn eller annen sensitiv informasjon. I forskningsprosessen arbeidet jeg alene, men en fag-kollega med erfaring fra nettundervisning engasjerte seg og var involvert i problemstillinger som dukket opp gjennom hele utviklings- og gjennomføringsprosessen. Kollegaer knyttet til nettundervisning i GLU var medvirkende i utvalgte deler som omfattet innsikt i mer generelle spørsmål knyttet til nettundervisnigen, som foreksempel problematikken omkring uvillighet mot å aktivere pc-kameraene. 
Gjennom å være aktivt deltagende og tilstedeværende underveis i hele undervisnings-forløpet og i unders $\varnothing$ kelsessituasjonene observerte jeg at studentene stadig og i ulike sammenhenger refererte til min narrative presentasjon innledningsvis i studieåret, både som undervisningsform, i konkrete tilfeller og som utgangspunkt for en tydeligere faglig helhetsforståelse knyttet til skapende arbeid. Ved å benytte pedagogisk aksjonsforskning, og ved å forholde meg tett til de fenomenene som ble studert, dukket det opp behov for at stadig flere aspekt ved problemstillingen som trengte å belyses og utdypes nærmere, ikke minst som et resultat av ulike fortløpende refleksjonsrunder underveis. Ved å ta i bruk mitt innledende narrativ ved semesterstart, viste det seg at denne fellesopplevelsen utløste aktivitet i form av faglig interesse, deltakelse og engasjement, men også uredd søken etter å finne egne strategier i nettundervisningen. Videre har jeg foretatt et utvalg av undervisningsøktene basert på antakelser om hvor egnet de var til å gi informasjon relatert til problemstillingen. I analysen av observasjonsmaterialet i denne unders $\varnothing$ kelsen har jeg brukt ulike tilnærmingsmåter for å finne ut hvilken påvirkning lærers bruk av narrativ strategi i nettundervisningen har bidratt til. Jeg har søkt etter uttrykk for studentenes faglige meningsskaping i deres eget skapende arbeid, forstått som å tilegne seg ny informasjon, og omforme kunnskapsstoffet inn i nye faglige sammenhenger og hvordan modellæring forstått som stedfortredende forsterkning kommer til uttrykk gjennom unders $\varnothing$ kelsen. Unders $\varnothing$ kelsen søker også svar på hvordan lærerens bruk av narrativ strategi har inspirert studentene i deres eget skapende arbeid og hvordan dette inngår i deres forståelse av faget og i deres kommunikasjon med meg og medstudenter.

\section{INNLEDENDE NARRATIV SOM GRUNNLAG FOR ØKT FAGLIG INTERESSE, DELTAKELSE OG ENGASJEMENT}

Mine første registeringer av studentenes engasjement og ønske om aktiv deltagelse merket jeg meg allerede den første timen vi var samlet i nettklasserommet. Etter innstendige oppfordringer til studentene om å aktivisere kameraene så vi alle kunne se hverandre, var alle pålogget med aktive bilder så nær som to. Jeg startet innledende narrativ for å presentere meg. Allerede mens jeg delte det første bildet fra innledende narrativ på skjermen aktiviserte disse to studentene bildene av seg selv. Først den ene, tett fulgt av den andre. Dette tolket jeg i retning av at begge faktisk opplevde et behov for aktivt å oppsøke klassemiljøet ved å aktivisere skjermbildene av seg selv.

I første pausen etter presentasjonen av innledende narrativ, frøs de fleste studentene bildet av seg selv. To av studentene ble sittende igjen med aktive bilder gjennom pausen. Jeg registrerte følgende innledning til en samtale som utviklet seg mellom disse to studentene: 'Har du sett sånn symaskin?', sa den ene, 'Nei, det så moro ut!', sa den andre. Etter denne innledningen fortsatte studentene samtalen om hvor de var bosatt og om nettundervisning som form, fram til pausen var over. Jeg lot meg fascinere av at innledende narrativ hadde påvirket utgangspunktet for spontant engasjement hos disse to studentene, som impulsivt innledet en samtale med referanse til min bruk av digital symaskin. Jeg tolket situasjonen slik at to fra før ukjente personer brukte en felles estetisk opplevelse som inspirasjon til å skape kontakt.

Utover i semesteret utviklet det seg raskt et fremtredende samarbeid mellom nettstudentene, som i stor grad var knyttet til innledende narrativ. Studentene brukte etter hvert også referanser til innledende narrativ som grunnlag for å drøfte hverandres tilnærminger til oppgavene. Aktivitet og innhold som dukket opp i sammenheng med kommentarene i chatte-feltet i nettklasserommet skapte på mange måter en synergieffekt, ved at studentene både engasjerte seg og ble inspirert og engasjert. Dette var med å skape en positiv stemning i det digitale klasserommet.

Nettstudentene i kunst og håndverk møtes fem dager i semesteret til undervisning i spesialverkstedene på campus. I denne samlingen var mitt ansvar lagt til den første dagen, der tegning og bildearbeid var tema. Undervisningen var lagt til et prosjektrom, et stort nøytralt innredet rom med spesielt gunstig belysning. Den ene delen av rommet var tilrettelagt for tegnearbeid ved staffelier og den andre delen som en samlingssone med prosjektor og stoler. Rommet var ferdigrigget dagen $f \varnothing r$. 
Noen studenter satt allerede langs veggen i korridoren utenfor før undervisningen startet. I det jeg passerte overhørte jeg deler av en samtale mellom dem: «.... tror jeg likte sauen best», sa den ene studenten, «Åh den bjørnen satt så koselig», svarte den andre.

I undervisningen ble det gjennomført tegneøvelser innenfor flere tegneteknikker. Tegneøvelsene fikk fram både høy aktivitet, og dyp konsentrasjon. Eksempler fra kunstområdet ble presentert i felles forum, og lærer hadde små innførings økter omkring øvelsenes hensikt etterfulgt av demonstrasjon av teknikk. Så fulgte en lang rekke tegneøvelser, som, hver på sitt vis, fikk frem både frustrasjon, smil og latter. Studentene beveget seg/løp fra det ene staffeliet til det andre for å se på hverandres bilder underveis i arbeidet, spørsmål som gikk igjen var: «Hvordan har du fått til det, kan du vise?», «Så fint, det vil jeg også prøve på»., «Hva var det denne teknikken het igjen?» I refleksjonsrunden i etterkant av den første tegne $\varnothing k$ ten viste studentene et tydelig engasjement i forhold til den nytteverdien de ulike tegneøvelsene kunne ha i skole og undervisning. Det dukket opp et uventet spørsmål som refererte direkte til innledende narrativ, som jeg hadde presentert innledningsvis til året, om det var så at jeg 'sang folkemusikk' og spørsmål om jeg kunne synge for dem. Stemningen i rommet og situasjonen innbød til fortrolighet. Jeg fant frem bildene til visa de allerede hadde møtt og sang alle versene.

Jeg spurte om studentene ikke syntes det var rart at jeg stod fremfor dem i kunst og håndverksundervisningen og sang? Jeg benyttet samtidig situasjonen til å fortelle studentene at jeg hadde vært spent på om de ville oppfatte presentasjonen innledningsvis til året som påtrengende informasjon eller selvskryt. Studentene fulgte opp med disse svarene: "Nei, det er fint», sa en, "Det er første gangen en lærer forteller om seg selv sånn», sa en annen, "Jeg var litt spent på å treffe deg, det var så moro å se bildene», sa en tredje, "Det er jo ikke så rart at en formingslærer lager bilder da», sa en fjerde og avrundet samtalen.

Innholdet i samtalen mellom studentene da jeg kom for å låse opp rommet om morgenen, dreide seg tydeligvis om noen av motivene fra mine tekstile bilder $\mathrm{i}$ innledende narrativ. Jeg tolket situasjonen som om dette handlet om en fellesreferanse for å oppnå kontakt. Jeg lot meg fascinere av at studentene hadde kunnet memorere for så nå å beskrive innholdet i bildene etter flere uker.

Aktivitetsnivået $\mathrm{i}$ klassen varierte fra stille og konsentrert arbeidsro da studentene arbeidet ved staffeliene, til et og annet utbrudd av frustrasjon eller latter. Jeg merket meg at studentene imiterte mine handlinger både kroppslig hvordan jeg stilte meg foran staffeliet, hvordan jeg plasserte bena og mer faglig i forhold til hvordan jeg 'angrep' tegneunderlaget på staffeliet med tegneredskapene. Mellom tegneøvelsene var det full aktivitet, jeg tolket stemningen i rommet som positiv og vennlig. Studentene beveget seg fra staffeli til staffeli for å se på hverandres bilder. De imiterte også på ulikt vis og i varierende grad hverandres angrepsstrategier og inn-hold i oppgaveløsningene, og de førsøkte ikke å

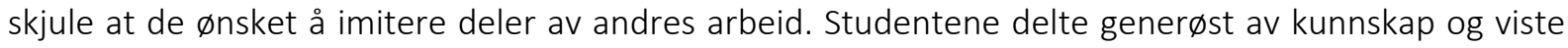
villig ferdigheter til medstudentene. Jeg tegnet raske observasjonsskisser av hvem som imiterte hvem i klasserommet og fortsatte med det dagen ut. Jeg fanget opp at det i samtalene mellom studentene både ble referert til selve aktiviteten, teknikkens navn og produktene.

Da studentene spurte om jeg kunne synge for dem, forstod jeg ut ifra situasjonen at en gruppe studenter hadde tolket og diskutert hva jeg egentlig hadde sagt i mitt innledende narrativ, om jeg ut $\varnothing$ vde sang eller ikke. Atmosfæren og studentenes holdning og blikk fikk meg til å fortsette både sangen og bildevisningen hele visa ut. Da jeg avsluttet sangen ble det litt stille, men ikke beklemt.

Min tolkning av situasjonene som er beskrevet ovenfor var at mitt innledende narrativ hadde vært med på å skape grobunn for aktivitet og engasjement i et felleskap hvor studentene i samarbeid og i samhandling vurderte hverandre konstruktivt, lo og hadde en vennlig innstilling. Jeg observerte også at studentene i фkende grad tok i bruk spesifikt faglige begrep, både i samtalen seg imellom og når de henvendte seg til lærer, og at studentene benyttet både lærer og medstudenter som modeller. I etterkant engasjerte de fleste studentene seg også aktivt og uredd i refleksjon og diskusjon rundt fagdidaktiske spørsmål knyttet til bruk og tilpassing av spesifikke tegneøvelser på ulike trinn i grunnskolen på en inspirert og kreativ måte. 


\section{INNLEDENDE NARRATIV SOM GRUNNLAG FOR STUDENTENES EGNE VALG AV STRATEGIER}

I nettklasserommet merket jeg meg umiddelbart at de individuelle presentasjonene fra studentene hadde et tydelig subjektivt preg når de skulle begrunne sitt fagvalg. De fleste be-nyttet blant annet en fri fortellerform med referanser til skapende virksomhet innbakt i eller som ramme rundt sine begrunnelser. Det ble referert til ulike innholdsstrukturer i faget, både i form av bildebehandlingsteknikker i arbeid med Photoshop, i ønske om opplæring i ulike teknikker innen bildeskaping som kunne utnyttes i bloggsammenheng og gjennom eksempelet med vedkurven hvor forventningene var knyttet til blant annet materialkunnskap. En student refererte også til formkulturens plass i den skolen hvor hun hadde vært vikar.

Studenten som imiterte begrepet 'fantasiverden' da hun skulle forklare sitt eget illustrasjonsarbeid, tolket jeg slik at studenten lot seg inspirere til å imitere begrepet fra innledende narrativ. For å tydeliggjøre hvilken betydning dette hadde hatt i min bildeprosess understreket jeg verdien av fantasibruk og ordla meg slik 'i min fantasiverden'. Det var interessant å merke seg at denne studenten faktisk nølte litt og liksom tok sats da hun tok i bruk begrepet, som om hun virkelig våget å gjøre noe for første gang.

Studenten som viste til egen blogg og delte bloggadressa i chattefeltet tolket jeg slik at innledende narrativ hadde satt henne på et klargjørende spor for et personlig behov for selv å utvikle illustrerende bilder til bloggen gjennom å lære noe om farger, form og komposisjon. Studenten med vedkurven lot seg inspirere av studenten som delte bloggadressen, ved å dele et foto på skjermen. Både min bruk av innledende narrativ, og momenter fra hva de andre studentene sa og gjorde ble brukt som modell for meningsinnhold i redegjørelsene for valg av kunst og håndverk i fagkretsen.

Studentene hadde uken før fått utlevert en flerdelt problembasert oppgave som gikk ut på å utvikle et grafisk design for fremsiden på en bildebok rettet mot barn. Denne $\varnothing$ kten skulle studentene møte til nettveiledning i det digitale klasserommet, hvor en og en skulle presentere sine ideer og refleksjoner i forhold til oppgaven innenfor bildeområdet grafisk design.

I forkant av veiledningen hadde jeg publisert en liste på læringsplattformen som viste fremføringstidspunkt for hver enkelt student. Det var avsatt totalt 12 minutter til hver, hvorav ca. 8 minutter beregnes til selve presentasjonen, to minutter til veiledning og tilbakemelding fra lærer. Medstudenter kommenterer fortløpende i chattefeltet. De siste to minuttene brukes til opplasting og deling av nestemann sitt dokument.

På tross av at det hadde gått mange uker siden jeg presenterte meg i innledningen av året, var det fire studenter som brukte innledende narrativ som grunnlag for å forklare hva og hvordan de hadde reflektert i og rundt bildeutformingen. Dette er noen av svarene: «Jeg liker så godt formen, men også innholdet i disse Appene og vil at de skal ha en plass i bildet, nesten sånn som du gjorde med sangen som du brukte». "Jeg vil prøve å bruke mest forskjellige hvitnyanser, litt som du viste med trådene til sauen, tror det blir fint mot sort kullstift». «Jeg tenkte på dyrene som du viste oss og så fikk jeg så lyst og gi mine noen menneskelige trekk». «Åh jeg er ikke fornøyd ennå jeg har gjort om og gjort om jeg får det ikke slik jeg ser det for meg, du sa også at du noen ganger måtte gjøre flere ganger?» Ingen studenter hadde gjennomført veiledning på denne måten før. Jeg henvendte meg direkte til en student som tydelig hadde lagt ned mye arbeid i presentasjonen og spurte hvordan hun hadde gått fram. Hun svarte: «Ja, jeg prøvde jo å gjøre litt sånn som deg, men det blir jo helt annerledes fordi denne oppgaven var noe helt annet og handler jo bare om idefasen».

Oppfølgingsspørsmål fra meg: "Kan du si hva du gjorde som du hadde lært av min presentasjon?» Studenten svarte: «i alle fall det å vise bilder og snakke samtidig». I chattefeltet hadde andre studenter fylt på med utsagn hvor det stod: «Bare vise få tydelige bilder og ikke en haug», «Kan heller tydeliggjøre med snakk», "som en grunnleggende forutsetning for det videre arbeidet», "har hatt fotofortelling i norsken». En student sa: «Du når de bildene dine hang på snora var det nesten det samme vi gjør nå?»

Den siste timen i nettklasserommet skulle brukes til å introdusere studentene for kreativitetsmodellen fra pensumboka Slagkraft av Erik Lerdahl (2007). Modellen er forholdsvis kompleks og den inneholder også en rekke fagbegreper som er grunnleggende for forståelse av modellens struktur. I tilknytning til dette undervisningsforløpet var det også avsatt plass til avklarende spørsmål og 
kommentarer fra studentene. Jeg lot meg imponere over både engasje-ment, struktur og innhold i det studentene presenterte i veiledningen. Studentene var godt for-beredt, og var ikke redde for å gjøre feil, de utviste både ro og mestringsforventning i vei-lednings-situasjonen. Flere henvisninger til innledende narrativ som presentasjonsform viste seg å ha vært grunnleggende for studentene, både for ideutviklingsarbeidet, men også i andre sammenhenger. Studentene viser til at de har hatt om fotofortelling i norsk som kan minne dem om innledende narrativ. Denne veiledingssituasjonen viste slik tydelig hvordan innledende narrativ hadde fungert som et allsidig refleksjonsgrunnlag. En av studentene hadde også et klart bilde av ideutviklingsprosessens betydning for den skapende prosessen helhetlig sett. Dette viser hun ved å innplassere ideutvikling som en viktig del i den helhetlige skapende prosessen, på denne måten viser hun hvordan hun skaper mening mellom sammenhenger i faget som trolig utviklet og utvidet hennes forståelse av fagets strukturer. Innledende narrativ ble i flere sammenhenger løftet fram som modell for studentenes forståelse og meningsdanning i faget, men nå først og fremst som eksemplifisering for å forklare egne refleksjoner. Jeg valgte å benytte innledende narrativ til eksemplifisering og som forklaringsgrunnlag for parameterne i den kreative modellen. Dette viste seg å være fruktbart og hensiktsmessig i tilknytning til det å innpasse og diskutere strukturene i innledende narrativ opp mot kreativitets-modellen. Ved å benytte innholdet fra innledende narrativ som kjent stoff til eksemplifisering kunne studentene slik i stor grad kjenne seg igjen, involvere seg og være deltakende i formidlingen og forklaringen av modellens deler. Chattefeltet har fått en sentral plass i det digitale klasserommet ved at studentenes kommentarer forekommer i hele setninger også med innhold av refleksjon.

Innledende narrativ ble benyttet som eksemplifiseringsgrunnlag når studentene skulle beskrive og forklare. Flere ganger gjennom semesteret brukte studentene formuleringer i samtaler seg imellom, for eksempel: «som da hun viste oss», eller «da hun snakket om» og «som du viste oss, da ...». Eksemplene fra veiledningen viser at studentene både refererer til og imiterer innledende narrativ, som de tar i bruk på en idemessig måte i eget skapende arbeid med teknikker, verktøy og materialer og i presentasjoner av egne arbeid i studieforløpet. Et eksempel hentet fra studenten som viste til inntrykk fra innledende narrativ ved å si: «Jeg vil prøve å bruke mest forskjellige hvitnyanser, litt som du viste med trådene til sauen, tror det blir fint mot sort kullstift». Slike eksempel på imitasjon av andres arbeid kan forstås som eksempel på det Bandura (1962) kaller stedfortredende forsterkning. Han forklarer stedfortredende forsterkning ved at det meste hadde vært vanskelig å få til hvis vi ikke hadde sett noen gjøre det før oss. Bandura (1986, s. 142-181) beskriver disse prosessene som aktive læringsformer hvor det handler mer om en selvstendig gjenskaping enn kopi og gjentakelse.

Studenten som stod fast i arbeidet og var rådvill: «Åh jeg er ikke fornøyd ennå jeg har gjort om og gjort om jeg får det ikke slik jeg ser det for meg, du sa også at du noen ganger måtte gjøre flere ganger?» Hun viser her til innholdet i innledende narrativ hvor jeg hadde vektlagt ideutvikling og idefasens grunnleggende viktighet og om hvor frustrerende fasen kunne fortone seg fordi alle mulige Iøsninger lå åpne, og at utvalg og vurdering måtte utdypes og foretas. I tilknytning til denne veiledningen ble strategiske punkt i innledende narrativ igjen løftet frem slik at studenten kunne orientere seg om og utdype idefasen, og slik ta de nødvendige utvalg og vurderinger som krevdes i forhold til materialer og teknikker. Slik forståelse av idefasens innhold handler ifølge Bruner (1970) om utvikling og utdyping av de grunnleggende strukturenes kompleksitet - her eksemplifisert gjennom bildeskaping. Gjennom bruk av strategiske punkter i henhold til innledende narrativ mener jeg at studenten utviklet $\varnothing$ kt innsikt i skapende arbeid, noe som gjorde henne bedre i stand til utvikling av en mer sensitiv visuell og kommunikativ oppmerksomhet i nettundervisningen. Studenten som sa: «Ja, jeg prøvde jo å gjøre litt sånn som deg, men det blir jo helt annerledes fordi denne oppgaven var noe helt annet og handler jo bare om idefasen» viser tydelig hvordan narrativ strategi hadde fungert som refleksjonsgrunnlag $\mathrm{i}$ prosessen, ved at studenten abstraherer kjent stoff og tilpasser dette i nye sammenhenger og ved å vise hvordan hun har gått frem for å utvikle kunnskap. Eksempler på modellæring kom til syne både som imitasjon og i mer idemessig forstand i nettundervisningen. For eksempel kan studenten som imiterte begrepet 'fantasiverden' og de andre studentene som uoppfordret la mye vekt på å innlemme egne erfaringer med skapende arbeid i presentasjonen av dem selv, være eksempler på en idemessig måte å benytte modellæring på. Bandura (1986) sin teori om modellæring vektlegger viktigheten av flere 
modeller i læringsprosessen. Gjennom undervisningsøkten viser det seg at det ikke bare er faglæreren som fungerer som modell, men det viser seg også at de andre studentene som inngår i den sosiale læringen fungerer som modeller for hverandre. I studentenes referanser til motivasjon for valg av kunst og håndverk i fagkretsen er det sammenfall med hva Bruner legger i oppdagelseslæring. Oppdagelseslæringen relateres til studentenes forforståelse av faget, gjennom oppdagelsene de gjorde i forhold til å gjenkjenne strukturer i faget, så som en spesiell teknikk, bildearbeid, materialtilegning og formkultur. Disse oppdagelsene vil jeg hevde ga grunnlaget for spiralæring ved at studentene gjentatte ganger sirkulerte, utviklet og utvidet, ulike sider av disse underliggende strukturene faget.

Det kom frem av observasjonen i verkstedet at alle studentene, på et eller annet tidspunkt, hadde fungert som modell for andre. Ifølge Bandura (1986) kan modellene oppfattes som informanter. Observasjoner gjennom modellæringen kan sees på som informasjons-behandling hovedsakelig i form av visuelle og verbale konstruksjoner (Bandura, 1986, s. 51-53). I følge Bandura dreier dette seg om et idebetont forhold i modellæringen, studentenes måte å benytte modellæring på tolker jeg som signaler i retning av å være eksempler på idemessig modeller, en form for læring som ifølge Bandura er en prosess som går fra å iaktta andre for så å danne seg en egen ide om hvordan ny atferd utøves i en målrettet handling. Relasjonene mellom informanten og de andre ble på denne måten ikke et mekanisk kopiert forhold, men mer som et resultat av en synergieffekt som utviklet seg mellom medlemmene i studentgruppen, både gjennom personlige og mer tilfeldige henvendelser til hverandre. I verksteds-sammen-hengen kommer det tydelig frem at flere modeller benyttes, både faglærer, men også med-studentene fungerer som modeller for hverandre.

Mitt inntrykk er at studentene gjennom imitasjon oppdaget deler av faget, for eksempel som sammenhenger mellom tegneredskap og bruk, eller angrepsmåte og konsekvenser for resultatet, innen bildeskapingen. Dette harmonerer med hva Bruner (1997) legger i å oppdage og utvide vekselvis mellom deler og helheter i aktiv søking etter form. Studentene var uredde i bildearbeidet og ikke redde for å vise hverandre hva som gikk galt, og de viste glede over hva som gikk bra og delte kunnskapen villig. I påfølgende oppsummering og refleksjon viste studentene også til bildearbeid i skolen og hvordan tegneoppgaven kunne brytes opp og settes sammen på nye måter for at de skulle tilpasses de ulike klassetrinnene. I dette eksempelet ser jeg et sammenfall med at studentene hadde dannet seg en forståelse av underliggende strukturer, som i denne sammenhengen hva bildeskaping kan være og ikke minst improvisere over deler som ulike teknikker, vanskegrad og materialerfaringer, og dele opp innholdet og sette sammen på nye måter i en didaktisk sammenheng.

\section{KONKLUSJON}

Gjennom semesteret utviklet det seg stadig tydeligere både formelle og mer uformelle kanaler for nettdialog, både mellom studentene og mellom lærere og studenter. Også i slike dialoger benyttet studentene stadig oftere fagspråk og formuleringer som også kom til uttrykk i ulike skriftlige formuleringer. Det var flere tegn som kunne tyde på at studentene hadde utviklet et annet fokus på både innhold og form i sammenheng med skapende prosesser og skapende arbeid. Jeg oppdaget at studentene begynte å bruke forskjellige faglige referanser fra mitt innledende narrativ. Jeg vil hevde at studentene gjennom min bruk av narrativ strategi også utviklet et dypere fokus på skapende arbeid som gjorde dem bedre rustet til å gi mer sensitiv oppmerksomhet til så vel visuell som verbal kommunikasjon. Jeg vil også hevde at bruk av innledende narrativ ga studentene noen eksempler og begreper til å kunne kommunisere omkring kunst og håndverksfaglig arbeid. Narrativet ble en fellesreferanse som studentene kunne ty til for å bli kjent med hverandre.

Flere ganger gjennom semesteret brukte studentene formuleringer i samtaler seg imellom hvor de refererte til innledende narrativ ved å si 'som da hun viste oss', eller 'da hun snakket om' og 'som du viste oss, da ...'. Min narrative presentasjon ble i flere tilfeller gjennom året benyttet både som bakgrunn for konkretisering av studentenes eget skapende arbeid, og det ble brukt som eksemplifisering når studentene skulle forklare eget arbeid. En mulig tolking av det som skjedde kan trolig ha sammenheng med endring av min presentasjonsmåte i retning av en mer subjektivt beskrivende og personlig form, noe som gjorde at læringsbetingelsene endret seg. Det er også ting som tyder på at dette kan ha påvirket 
og endret studentenes oppfatning av hvordan læring finner sted. Det er slik flere ting som peker mot at ansvarlig faglig formidler og veileder fremsto som en mer troverdig rollemodell for studentene. Det viste seg at innledende narrativ som presentasjon hadde dannet kjernen i en slags undervisningsressurs i form av en grunnleggende forelesning, som raskt viste seg å ha satt studentene på sporet av fagets egenart. Dette kom til syne både gjennom en faglig begrepsbruk og i begrepsforståelsene, i studentenes skapende arbeid og i presentasjonen av eget skapende arbeid. Ved at lærer viser et eget utviklet faglig bidrag på denne måten ga studentene et orienteringsgrunnlag og motivasjon i det faglige arbeidet.

Læringsstrategiene studentene tok i bruk for å skape meningssammenheng i kunst og håndverksfaget, kom til syne gjennom semesteret ved at studentene stadig var på leting etter fagets deler og fors $\varnothing$ kte å innpasse disse i helheter som for eksempel innenfor bilde-, kreativitets- og designområdet. Jeg finner det hensiktsmessig å se studentenes strategier i lys av både Bandura $(1986,1997)$ og Bruner (1960, 1975, 1997) sine teorier om modellæring og oppdagelseslæring. Modellæring fremkom i undervisningen både i det digitale klasserommet og på campussamlingen i form av å være intuitiv, umiddelbar og rettet mot mer kortsiktige mål, fremtredende som mer eller mindre kontinuerlige prosesser. Spirallæring fremkom mer som overordnet og analytisk rettet, og viste seg som den langsiktige røde tråden som skaper sammenheng mellom fagets deler og helheter, forstått som strukturer i faget. Disse læringsformene utfylte hverandre ved å inneha de nevnte ulike egenskapene. Jeg vil hevde at disse sammenhengene var et vesentlig grunnlag for at studentene utviklet viktig kortsiktig overflate- og delkunnskap som sammen med analytisk helhetstenkning ga faglige perspektiv og dybdelæring. Studentenes abstraksjonsnivå ble slik tydelig gjennom semesteret. Det synes som om studentene imiterte forbilder kontinuerlig, både fra nettet, fra lærer og de andre studentene, samtidig som de tydelig uttrykte forståelse for både deler og helheter i en hel bildeskapende prosess. 


\section{LITTERATUR}

Aukrust, V. (1997). Introduksjon til Utdanningskultur og læring. I J. Bruner, Utdanningskultur og læring. Ad Notam Gyldendal.

Austring, B.D \& Sørensen, M. (2006). AEstetik og Læring. Grundbog om æstetiske læreprocesser. Hans Reitzels Forlag.

Austring, B.D \& Sørensen, M. (2019). ÆEstetiske læreprocesser i skolen. I K. H. Karlsen \& G. B. Bjørnstad (red.), Skaperglede, engasjement og utforskertrang. Nye perspektiver på estetiske- \& tverrfaglige undervisningsmetoder i pedagogisk virksomhet (ss. 259-277). Universitetsforlaget.

Bandura, A. (1986). Social foundations of thought and action: a social cognitive theory. Prentice-Hall.

Bandura, A. (1997). Self-efficacy: the exercise of control. Freeman.

Bandura, A. (1962). Social learning through imitation. I: M. R. Jones (Ed.), Nebraska Symposium on Motivation, 1962 (pp. 211-274). University of Nebraska Press.

Baskår, E. (2006). Når det tekstile møter det digitale. Unders økelser gjennom eget og studenters skapende arbeid. (Masteroppgave). Høgskolen i Telemark, Notodden.

Bruner, J. (1960). The Process of Education. The President and Fellows of Harvard College.

Bruner, J. (1970). Om å lære. Dreyers forlag.

Bruner, J. (1997): Utdanningskultur og læring. Ad Notam Gyldendal.

Bruner, J. (1990). Acts of Meaning. Harvard University Press.

Carr, W. \& Kemmis, S. (1986). Becoming Critical: Educational Knowledge and Action Research. Falmer Press.

Eisner, E. W. (1979). The educational imagination: On the design and evaluation of school programs. Macmillan.

Eisner, E. W. (2002). The Design and Evaluation of School Programs, On the design and evaluation of school programs (3rd. ed.). Macmillan.

Elliott, J. (1991). Action Research for Educational Change. Open University Press.

Engh, R., Dobson, S. \& Høihilder, E. K. (2007). Vurdering for læring. Høyskoleforlaget.

Fossland, T. (2015). Digitale læringsformer i høyere utdanning. Universitetsforlaget.

Fossland, T. \& Ramberg, K. R. (2016). Kvalitetskjeden i høyere utdanning - en guide for digital kompetanse og undervisningskvalitet. (Norgesuniversitetets skriftserie 1/2016). Norgesuniversitetet. https://diku.no/content/download/1136/file/1-2016-guide-for-digital-kompetanse-og.pdf

Groth, C. (2017). Making sense through hands. Design and craft practice analysed as embodied cognition (PhD, Aalto University, Helsinki). http://urn.fi/URN:ISBN:978-952-60-7130-5

Gulliksen, M. (2017). Making matters? Unpacking the role of practical aesthetic making activities in the general education through the theoretical lens of embodied learning. Cogent Education, 4(1), https://doi.org/10.1080/2331186X.2017.1415108

Hattie, J. (2012). Visible learning for teachers. Routledge

Hiim, H. (2010). Pedagogisk aksjonsforskning. Eksempler, prinsipper og kunnskapsfilosofisk grunnlag. Gyldendal Akademisk.

Hiim, H. (2013). Praksisbasert yrkesutdanning. Hvordan utvikle relevant yrkesutdanning for elever og arbeidsliv? Gyldendal Akademisk.

Kemmis, S. (2001). Exploring the Relevance of Critical Theory for Action Research: Emancipatory Action Research in the Footsteps of Jurgen Habermas. I P. Reason \& H. Bradbury (red) Handbook of Action Research. (ss.91-102). Sage.

Kunnskapsdepartementet. (2010a). Nasjonale retningslinjer for grunnskolelærerutdanningen 1. - 7. trinn https://www.regjeringen.no/globalassets/upload/kd/rundskriv/2010/retningslinjer_grunnskolelaererutd anningen_1_7_trinn.pdf 
Kunnskapsdepartementet. (2010b). Nasjonale retningslinjer for grunnskolelærerutdanningen 5. - 10. trinn. https://www.regjeringen.no/globalassets/upload/kd/rundskriv/2010/retningslinjer_grunnskolelaererutd anningen_5_10_trinn.pdf

Kunnskapsdepartementet. (2017a). Overordnet del-verdier og prinsipper for grunnopplæringen. https://www.regjeringen.no/no/dokumenter/verdier-og-prinsipper-for-grunnopplaringen/id2570003/

Kunnskapsdepartementet. (2017b). Kultur for kvalitet i høyere utdanning (Meld. St. 16 (2016-2017)). https://www.regjeringen.no/no/dokumenter/meld.-st.-16-20162017/id2536007/.

Kähler, C. F. (2012). Det kompetente selv: en introduktion til Albert Banduras teori om selvkompetence og kontrol. Frydenlund.

Lerdahl, E. (2007). Slagkraft: Håndbok i idèutvikling. Gyldendal Akademisk.

Merleau-Ponty, M. (1994). Kroppens fenomenologi. Pax.

Molander, A. \& Smeby, J.-C. (red.). (2013). Profesjonsstudier II. Universitetsforlaget.

Postholm, M.B. \& Moen, T. (2018). Forsknings- og utviklingsarbeid i skolen. En metodebok for lærere, studenter og forskere. (2.utg.) Universitetsforlaget.

Riis, K. (2016). Designkundskabens DNA: Udforskning af designkundskab gennem designprocessen Mit DNA (Doctoral dissertation, Det humanistiske fakultet, Institutt for filosofi og religionsvitenskap, NTNU, Trondheim). http://hdl.handle.net/11250/2393093

Stenhouse, L. (1975). An Introduction to Curriculum Research and Development. Guilford.

Universitetet i Oslo. (2014). Ramnebryllup i kråkelund. [Dokumentasjonsprosjektet]. https://www.dokpro.uio.no/ballader/tekster html/f/f068 003.html

Utdanningsdirektoratet. (2016). Kunst og håndverk - fagets egenart. https://www.udir.no/laring-ogtrivsel/lareplanverket/fag/kunst-og-handverk/kunst-og-handverk---fagets-egenart/

Utdanningsdirektoratet. (2020). Læreplan i kunst og håndverk. (KHV01-02). https://www.udir.no/lk20/khv01-02

Vedeler, L. (2000). Bortenfor skillet mellom teori og praksis. Fagbokforlaget.

Whitehead, J. \& McNiff, J. (2006). Action research: living theory. Sage.

Zeichner, K. (2010). Rethinking the connections between campus courses and field experiences in college- and university based teacher education. Journal of Teacher Education. 61(1-2), 89-99.

https://doi.org/10.1177/0022487109347671 